\title{
PROFILES OF FOREIGN DIRECT INVESTMENT IN U.S. ENERGY 1993
}

MAY 1995

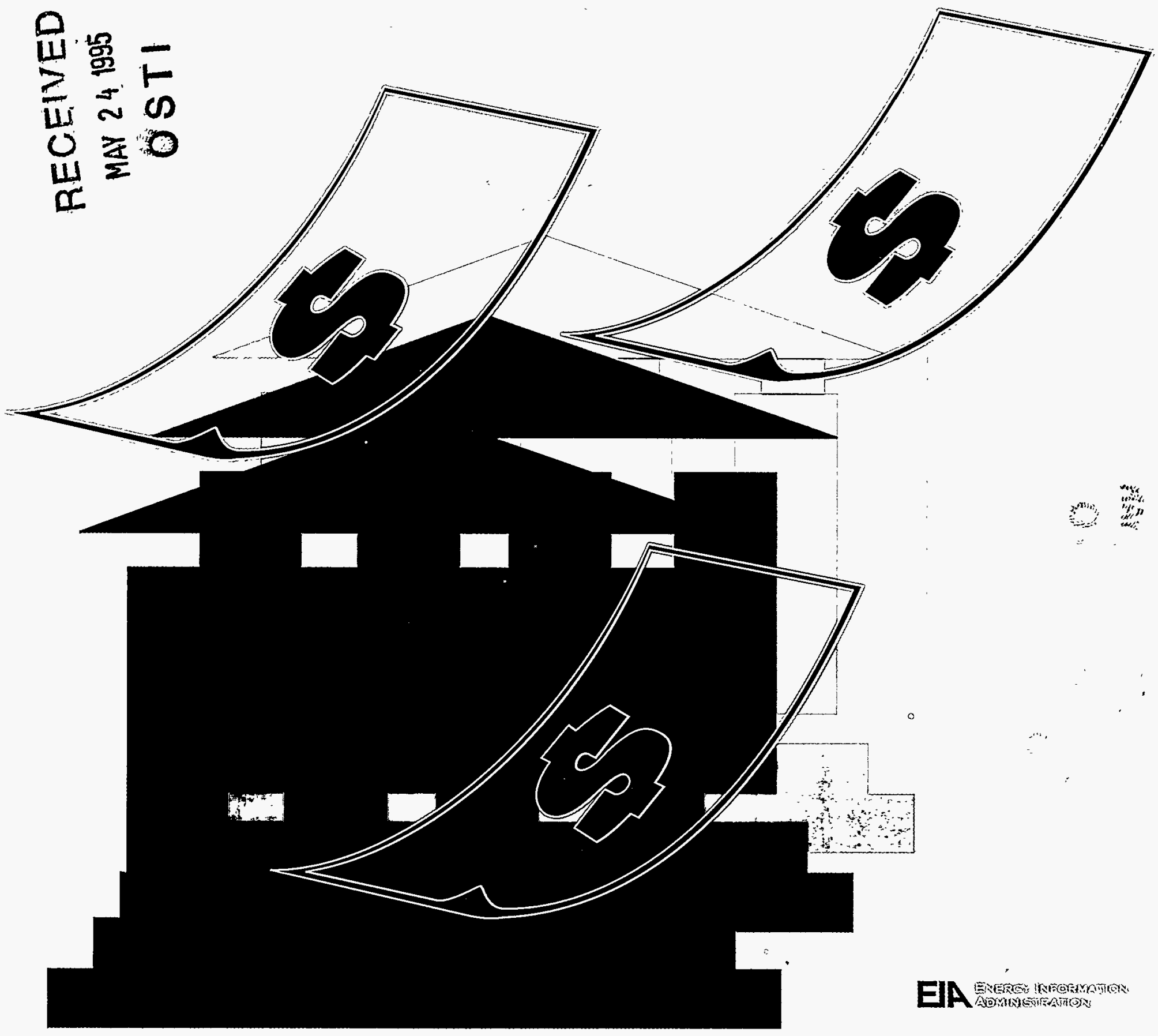


This publication and other Energy Information Administration (EIA) publications may be purchased from the Superintendent of Documents, U.S. Government Printing Office.

Telephone orders may be directed to:

Superintendent of Documents

U.S. Government Printing Office

Main Order Desk

(202) $512-1800$

FAX: (202) 512-2250

8 a.m. to $4: 30$ p.m., eastern time, M-F

\title{
All mail orders should be directed to:
}

\author{
U.S. Government Printing Office \\ P.O. Box 371954 \\ Pittsburgh, PA 15250-7954
}

Complimentary subscriptions and single issues are available to certain groups of subscribers, such as public and academic libraries, Federal, State, local and foreign governments, EIA survey respondents, and the media. For further information and for answers to questions on energy statistics, please contact EIA's National Energy Information Center. Address, telephone numbers, and hours are as follows:

\author{
National Energy Information Center, EI-231 \\ Energy Information Administration \\ Forrestal Building, Room 1F-048 \\ Washington, DC 20585 \\ (202)586-8800 \\ Internet E-Mail: INFOCIR@EIA.DOE.GOV \\ TTY: For people who are deaf or hard \\ of hearing: (202)586-1181 \\ 9 a.m. to 5 p.m., eastern time, M-F
}

Released for Printing: May 5, 1995

Printed with soy ink on recycled paper 


\section{DISCLAIMER}

Portions of this document may be illegible in electronic image products. Images are produced from the best available original document. 
DOE/EIA-0466(93)

Distribution Category UC-950

\title{
Profiles of Foreign Direct Investment in U.S. Energy 1993
}

\author{
May 1995
}

\author{
Energy Information Administration \\ Office of Energy Markets and End Use \\ U.S. Department of Energy \\ Washington, DC 20585
}

This report was prepared by the Energy Information Administration, the independent statistical and analytical agency within the Department of Energy. The information contained herein should not be construed as advocating or reflecting any policy position of the Department of Energy or of any other organization. 


\section{Contacts}

This report was prepared under the general direction of W. Calvin Kilgore, Director of the Office of Energy Markets and End Use of the Energy Information Administration. General questions concerning the content of the report may be referred to Mark E. Rodekohr, Director of the Energy Markets and Contingency
Information Division, at (202) 586-1130, and Mary E. Northup, Chief of the Financial Analysis Branch, at (202) 586-1445. For specific technical information concerning this report, contact Jon Rasmussen at (202) 586-1449 or Kevin Lillis at (202) 586-1395. 


\section{Contents}

Executive Summary $\ldots \ldots \ldots \ldots \ldots \ldots \ldots \ldots \ldots \ldots \ldots \ldots \ldots \ldots \ldots \ldots \ldots \ldots \ldots \ldots \ldots \ldots$

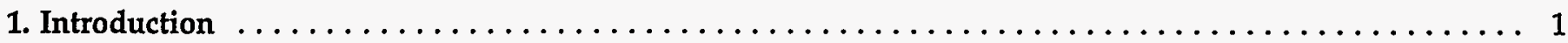

2. Foreign Acquisitions and Divestitures of U.S. Energy Assets in $1993 \ldots \ldots \ldots \ldots \ldots \ldots \ldots \ldots$

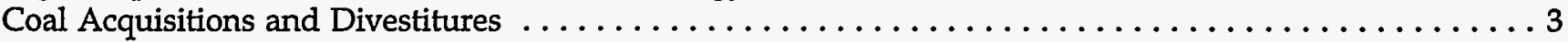

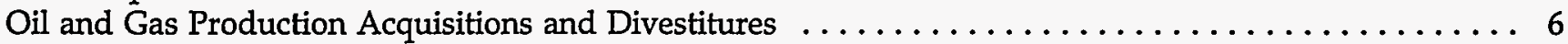

Refining/Marketing Acquisitions and Joint Ventures $\ldots \ldots \ldots \ldots \ldots \ldots \ldots \ldots \ldots \ldots \ldots \ldots$

3. Patterns of Overall Foreign Direct Investment $\ldots \ldots \ldots \ldots \ldots \ldots \ldots \ldots \ldots \ldots \ldots \ldots \ldots \ldots \ldots$

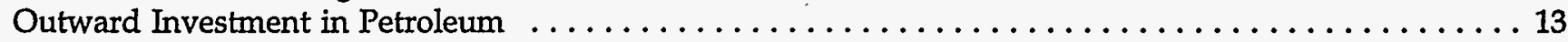

4. The Role and Financial Performance of Foreign-Affiliated Companies in U.S. Energy Operations . . . . 17

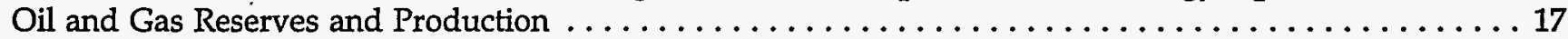

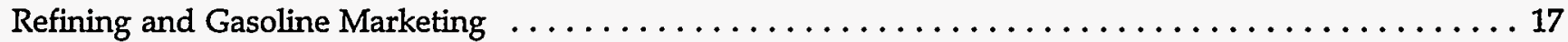

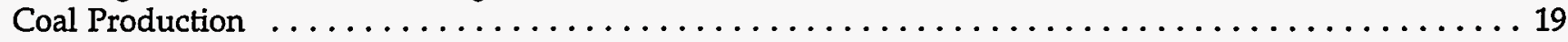

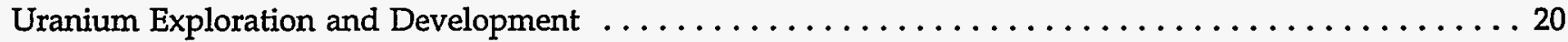

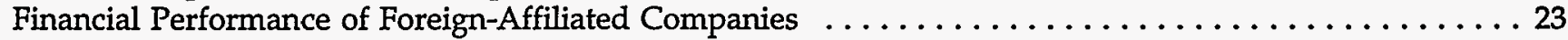

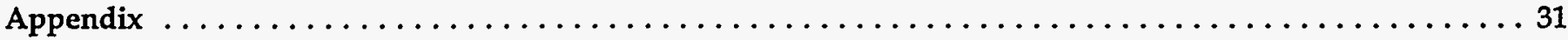

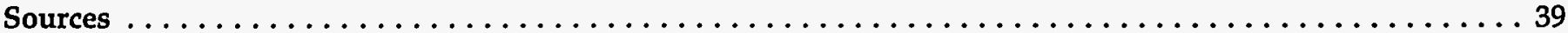




\section{Tables}

1. Value of FDI-Related Transactions in U.S. Energy, $1990-1993 \ldots \ldots \ldots \ldots \ldots \ldots \ldots \ldots \ldots \ldots \ldots \ldots$

2. Targets of Foreign Direct Investment in U.S. Industry, $1991-1993 \ldots \ldots \ldots \ldots \ldots \ldots \ldots \ldots \ldots \ldots . . \ldots$

3. Geographic Sources of Foreign Direct Investment in U.S. Industry, 1991-1993 . . . . . . . . . . . . 10

4. Foreign Direct Investment in U.S. Petroleum and Coal, $1980-1993 \ldots \ldots \ldots \ldots \ldots \ldots \ldots \ldots \ldots \ldots$

5. Geographic Sources of Foreign Direct Investment in U.S. Petroleum, 1991-1993 . . . . . . . . . . . 12

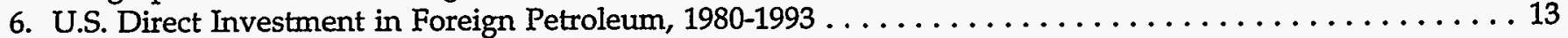

7. Net Production of Petroleum and Dry Natural Gas in the United States by Foreign-Affiliated

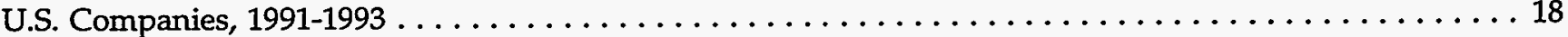

8. Domestic Oil and Dry Natural Gas Proved Reserves and Production for Foreign-Affiliated

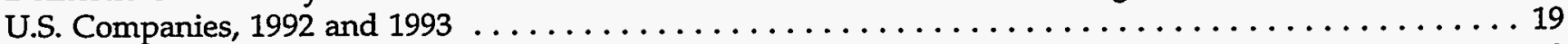

9. U.S. Refinery Operations of Foreign-Affiliated U.S. Companies, $1989-1993 \ldots \ldots \ldots \ldots \ldots \ldots \ldots \ldots \ldots . \ldots 20$

10. Branded Retail Outlets and Total Gasoline Supplied by Foreign-Affiliated U.S. Companies, 1989-1993 . . 21

11. Bituminous Coal and Lignite Production and Source of Ownership of Foreign-Affiliated Coal

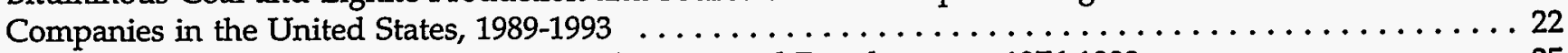

12. Foreign Participation in U.S. Uranium Exploration and Development, $1976-1993$. . . . . . . . . . . . 25

13. Selected Financial Information for Foreign-Affiliated U.S. Energy Companies, 1992-1993 . . . . . . . . . 26

A1. Completed Transactions by Size in the Petroleum Industry from January 1993 Through

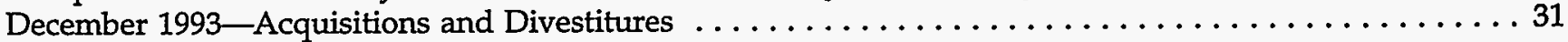

A2. Completed Transactions by Size in the Coal Industry from January 1993 Through

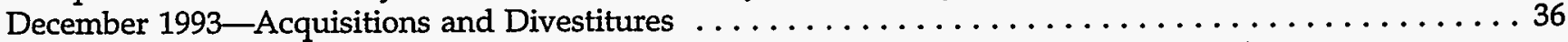

A3. Completed Transactions by Size in Other Energy Industries from January 1993 Through

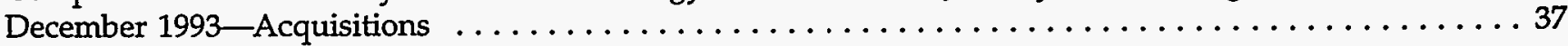

\section{Figures}

1. Value of FDI-Related Acquisitions in U.S. Energy and Annual Change in FDI Position in Petroleum

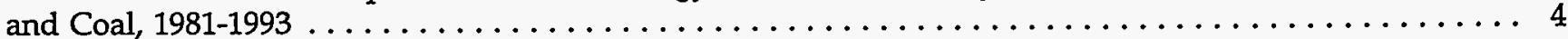

2. Value of FDI-Related Acquisitions by Energy Segment, $1981-1993 \ldots \ldots \ldots \ldots \ldots \ldots \ldots \ldots \ldots \ldots$

3. Exploration and Development Expenditures of the FRS Companies, 1981-1993 . . . . . . . . . . 14

4. Exploration and Development Expenditures, by Region, for FRS Companies, 1986, 1991, and 1993 . . . . 15

5. Production and Share of U.S. Total Bituminous Coal and Lignite for Foreign-Affiliated U.S. Companies,

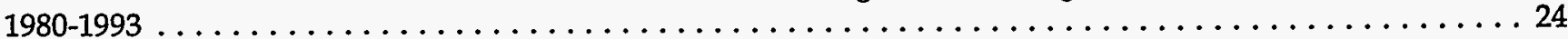

6. Return on Stockholders' Equity for Foreign-Affiliated U.S. Energy Companies, Other U.S. Energy

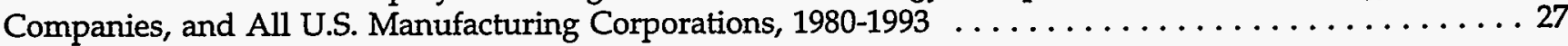




\section{Executive Summary}

Profiles of Foreign Direct Investment in U.S. Energy 1993 describes the role of foreign ownership in U.S. energy resources. This report also looks at the investment patterns of U.S. energy companies in other countries. The data used in this report come from the Energy Information Administration (EIA), the U.S. Department of Commerce, company annual reports, and public disclosures of investment activities.

Foreign companies, through their U.S.-based affiliates, play a significant role in U.S. energy production and processing. For example, in 1993, foreign-affiliated companies accounted for 30 percent of U.S. refining capacity, 28 percent of U.S. coal production, 15 percent of U.S. oil production, and 8 percent of U.S. natural gas production (Figure ES1). Foreign-affiliated companies also accounted for nearly a third of all U.S. gasoline sales and for ownership of a quarter of all retail gasoline outlets. In 1993, foreign affiliates continued to increase their presence in U.S. refining and coal production. In contrast, little change was reported in crude oil production, while a modest increase was

Figure ES1. Foreign Affiliates' Share of U.S. Production of Oil, Gas, and Coal, and U.S. Refining Capacity, 1980-1993

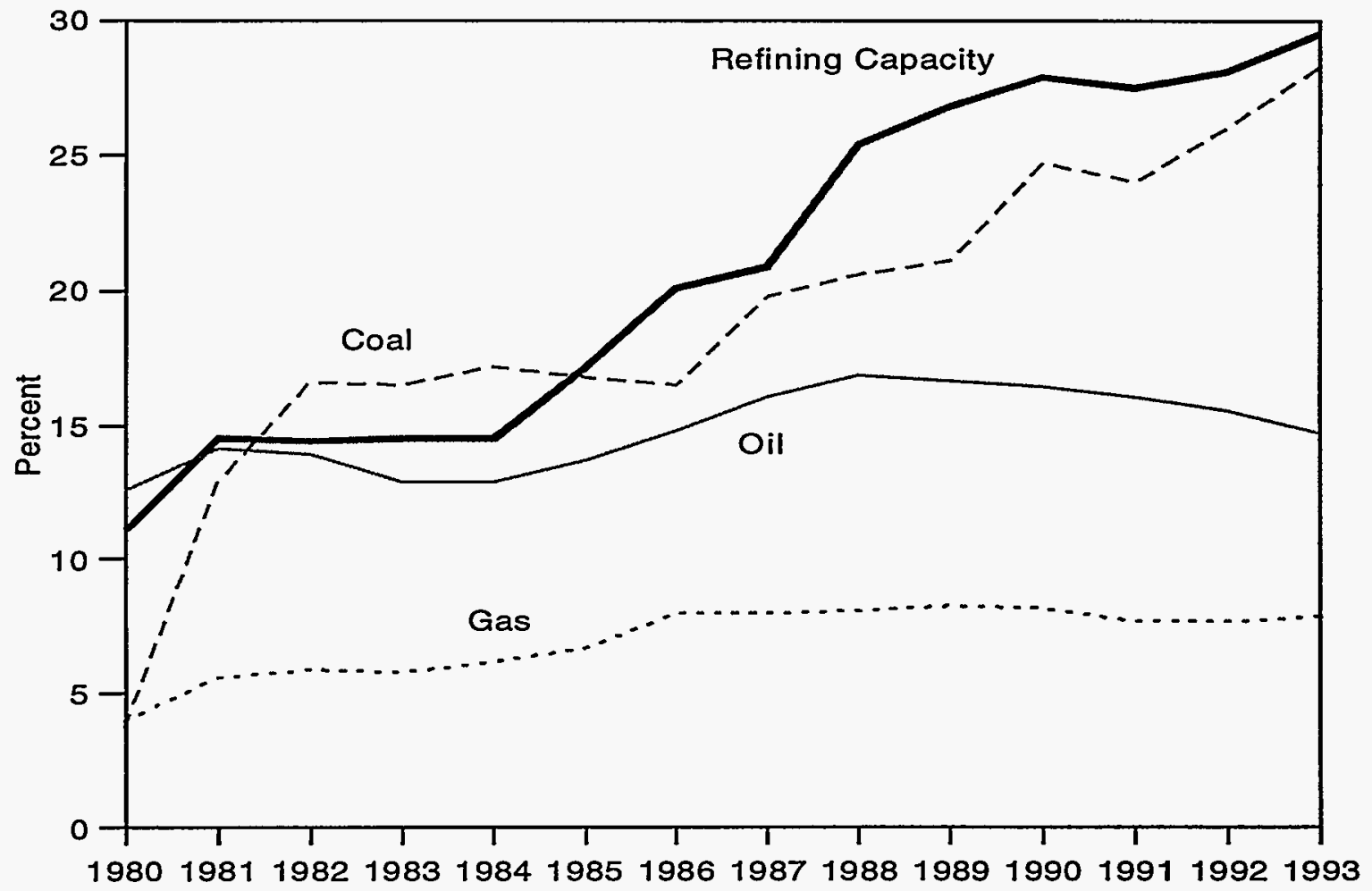

Sources: Tables 7, 9, 10, and 11 of Chapter 4 of this report. U.S. Department of Energy, Annual Report to Congress, DOE/S-0010(84) (Washington, DC, September 1984). Energy Information Administration, Profiles of Foreign Direct Investment in the U.S. Energy, 1983-1992, DOE/EIA-0466 (Washington, DC, 1984-1994). 
reported in the foreign-affiliates' share of domestic natural gas production.

In 1993, overall additions to the foreign direct investment position ${ }^{1}$ in the United States rose to $\$ 19.6$ billion from $\$ 6.9$ billion in 1992, which was the lowest level since 1972. Growth in the U.S. economy and increased earnings of foreign parent companies contributed to the rebound in additions to FDI in 1993.

In 1993, U.S. coal mining assets continued to be the most attractive target of investment for foreign investors in U.S. energy. As European mining companies prepare for the eventual elimination of national coal subsidies, the attractiveness of finding alternatives to high-priced European coal has grown considerably. The largest energy acquisition by a foreign investor in 1993 involved U.S. coal assets. British-based RTZ Corp., through its Kennecott subsidiary, acquired Nerco for $\$ 1.2$ billion.

After coal, the next most prominent target of foreign investors in U.S. energy during 1993 involved petro- leum refining and marketing assets. In 1993, the national petroleum companies of two major oil exporters-Mexico and Venezuela-increased their presence in U.S. refining, largely to ensure a more secure outlet for their exports of crude oil to the United States. The total investment associated with these transactions could eventually exceed $\$ 1.9$ billion. In 1993 , these two companies, together with the national oil company of Saudi Arabia, had ownership interests in refineries accounting for 11 percent of total U.S. refining capacity.

Oil and gas exploration and production (upstream petroleum) presented a mixed picture of foreign investor interest in 1993. Although the total value of upstream acquisitions by foreign interests, at $\$ 1.2$ billion, was at a five-year high, the value of divested upstream assets was about double the level of the previous year. This pattern of investment reflected the increased attraction of natural gas drilling and production, the expansion of deep-water drilling in the Gulf of Mexico, and cost-cutting through consolidation in the context of declining oil prices.

\footnotetext{
${ }^{1}$ The foreign direct investment (FDI) position is the cumulative net flow of funds between a foreign-affiliated company and its foreign owners. The U.S. Department of Commerce, the agency that collects data on FDI, measures FDI as the book value of foreign direct investors' equity in and net outstanding loans to their U.S. affiliates. The U.S. Department of Commerce defines a U.S. affiliate as a U.S. business enterprise in which one foreign direct investor owns 10 percent or more of the voting securities or the equivalent.
} 


\section{Introduction}

The purpose of this report is to provide an assessment of the degree of foreign ownership of energy assets in the United States. ${ }^{1}$ Section 657, Subpart 8 of the U.S. Department of Energy Organization Act (Public Law 95-91) requires an annual report to Congress which presents:

... to the extent practicable, a summary of activities in the United States by companies or persons which are foreign owned or controlled and which own or control United States energy sources and supplies, including the magnitude of annual foreign direct investment in the energy sector in the United States ... ${ }^{2}$

This report integrates and reviews information from a variety of sources, including Federal agencies and companies' certified financial statements, in order to present a clear, quantitative perspective on the role of foreign investors in the U.S. energy sector, on both an annual and a multiyear basis. The report is intended to better inform debate arising from concerns about foreign ownership of U.S. energy assets.

The report reviews the patterns of foreign ownership interests in U.S. energy enterprises, exclusive of portfolio investment. ${ }^{3}$ Throughout this report such foreign non-portfolio ownership interests in U.S. energy companies are referred to as "foreign direct investment," and the U.S. affiliates in which a foreign entity holds an ownership interest are referred to as "foreign-affiliated" U.S. enterprises or companies. All dollar amounts in this report are stated in terms of current dollars.

By definition, "a U.S. affiliate is a U.S. business enterprise in which a single foreign direct investor owns at least 10 percent of the voting securities, or the equivalent." ${ }^{\prime 4}$ It should be noted that holding 10 percent or more of a company's voting stock does not necessarily constitute control of that company. The determination of control is a complex and often subjective process in which many factors other than the percentage of ownership must be considered.

This report profiles the involvement of foreign-affiliated U.S. companies in the following areas: domestic oil and gas production, reserve holdings, refining and marketing activities, coal production, and uranium exploration and development. A financial profile of foreign-affiliated U.S. energy companies is presented, comparing data for 1992 and 1993. The report reviews recent acquisitions and divestitures of ownership interests in U.S. energy companies by foreign investors. This report is organized as follows:

- Foreign Acquisitions and Divestitures of U.S. Energy Assets in 1993

- Patterns of Overall Foreign Direct Investment in 1993

- The Role and Financial Performance of ForeignAffiliated Companies in U.S. Energy Operations in 1993.

Details of FDI transactions in 1993 are listed in the appendix. Information on acquisitions of ownership in U.S. energy enterprises was obtained from public disclosures of financial transactions and filings of Form 13$\mathrm{D}$ with the U.S. Securities and Exchange Commission. The information on the FDI position in the United States was derived from data published by the U.S. Department of Commerce. The data are obtained from

\footnotetext{
${ }^{1}$ See, for example, U.S. House of Representatives, Committee on Government Operations, The Adequacy of the Federal Response to Foreign Investment in the United States (August 1980), especially page 2.

${ }^{2}$ Versions of this report, for years prior to the 1983 reporting year, appeared in Appendix A in the U.S. Department of Energy's Secretary's Annual Report to Congress. Beginning with the 1983 reporting year, the annual report on foreign investment and ownership in U.S. energy has been published by the EIA. A report on exports of energy, required by the same legislation, is in the U.S. Department of Energy's Secretary's Annual Report to Congress 1991, DOE/S-0010(92) (Washington, DC, December 1992).

${ }^{3}$ Foreign ownership of less than 10 percent of a U.S. enterprise is classified as portfolio investment by the U.S. Department of Commerce.

${ }^{4}$ U.S. Department of Commerce, Bureau of Economic Analysis, Survey of Current Business (Washington, DC, June 1993), p. 53. Also, it should be noted that, consistent with its definition, foreign investment activities portrayed throughout this report do not include any foreign investment activities in connection with less than 10 percent ownership, which is known as portfolio investment.
} 
quarterly reports required of foreign-affiliated U.S. enterprises. Foreign direct investment is the cumulative net flow of funds between a foreign-affiliated company and its foreign owners. These capital flows consist of stock purchases and paid-in capital, retained earnings and other equity, and loans from and to foreign parents. ${ }^{5}$ It should be emphasized that investment flows out of, as well as into, the United States.

${ }^{5} \mathrm{~A}$ detailed discussion of FDI data collection and methodology is contained in, "A Guide to BEA Statistics on Foreign Direct Investment in the United States," U.S. Department of Commerce, Bureau of Economic Analysis, Survey of Current Business (Washington, DC, February 1990). 


\section{Foreign Acquisitions and Divestitures of U.S. Energy Assets in 1993}

The most direct indication of foreign investors' interest in U.S. energy is the pattern of their expenditures for acquisitions of U.S. energy assets and their divestitures of such assets. In 1993, acquisitions that affected the foreign direct investment position ("FDI-related" acquisitions) in U.S. petroleum and coal totaled $\$ 4.6$ billion (Table 1), up 91 percent from 1992 and above the $\$ 2-\$ 3$ billion range evident in recent years (Figure 1 ). The value of FDI-related divestitures (i.e., the sale of U.S. energy assets by foreign-affiliated companies) at $\$ 2.2$ billion, was up considerably from recent levels. Acquisition and divestiture patterns in 1993 indicate that coal was the primary energy interest of foreign investors, that foreign interest in U.S. refining revived, and that the value of oil and gas divestitures by foreign investors was about three-quarters the value of oil and gas acquisitions.

\section{Coal Acquisitions and Divestitures}

Coal operations accounted for 42 percent of the value of FDI-related acquisitions in U.S. energy in 1993 (Table 1). The $\$ 1.9$ billion of foreign acquisitions in coal mainly reflected the transactions of a single company. In 1993, RTZ Corp., through its Kennecott Corp.

Table 1. Value of FDI-Related Transactions in U.S. Energy, 1990-1993

(Million Dollars)

\begin{tabular}{|c|c|c|c|c|}
\hline Acquisitions/Divestitures & 1990 & 1991 & 1992 & 1993 \\
\hline \multicolumn{5}{|l|}{ Acquisitions } \\
\hline Oil and Gas Production ${ }^{a}$ & 901 & 1,043 & 949 & 1,246 \\
\hline Petroleum Refining, Marketing, and Transport ... & 1,040 & 103 & 173 & 1,264 \\
\hline 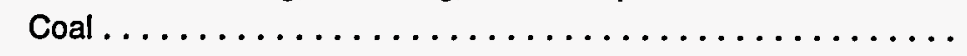 & 1,416 & 570 & 1,276 & 1,928 \\
\hline Other Energy $\ldots \ldots \ldots \ldots \ldots \ldots \ldots \ldots \ldots \ldots \ldots \ldots \ldots$ & 0 & 0 & 0 & 150 \\
\hline 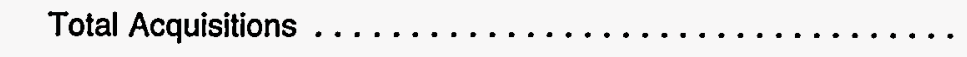 & 3,357 & 1,716 & 2,398 & 4,588 \\
\hline \multicolumn{5}{|l|}{ Divestitures } \\
\hline Oil and Gas Production ${ }^{\mathbf{a}}$ & 474 & 736 & 461 & 938 \\
\hline Petroleum Refining, Marketing, and Transport & 59 & 400 & 60 & 822 \\
\hline 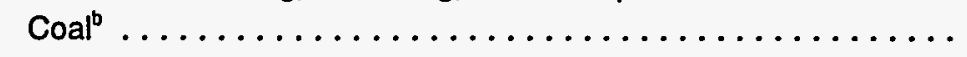 & 841 & 155 & 869 & 438 \\
\hline Other Energy $\ldots \ldots \ldots \ldots \ldots \ldots \ldots \ldots \ldots \ldots$ & 0 & 0 & 0 & 0 \\
\hline Total Divestitures $\ldots \ldots \ldots \ldots \ldots \ldots \ldots \ldots \ldots \ldots \ldots$ & 1,374 & 1,291 & 1,390 & 2,198 \\
\hline
\end{tabular}

${ }^{a}$ Includes drilling and drilling services.

b1990 includes Newmont Mining's sale of its 55-percent interest in Peabody Holding Company for \$726 million, while 1992 includes Shell Oil's divestiture of its coal operations for $\$ 850$ million.

Sources: 1993: Based on Tables A1, A2, and A3 in this report. 1992: Based on Tables A1 and A2 in Energy Information Administration Profiles of Foreign Direct Investment in U.S. Energy 1992, DOE/EIA-0466(92) (Washington, DC, May 1994). 1991: Based on Tables A1 and A2 in Energy Information Administration, Profiles of Foreign Direct Investment in U.S. Energy 1991, DOE/EIA-0466(91) (Washington, DC, April 1993). 1990: Based on Tables A1 and A2 in Energy Information Administration, Profiles of Foreign Direct Investment in U.S. Energy 1990, DOE/EIA-0466(90) (Washington, DC, April 1992).

\footnotetext{
${ }^{6}$ The foreign direct investment (FDI) position is the cumulative net flow of funds between a foreign-affiliated company and its foreign owners. The U.S. Department of Commerce, the agency that collects data on FDI, measures FDI as the book value of foreign direct investors' equity interest in and net outstanding loans to their U.S. affiliates. The Department of Commerce defines a U.S. affiliate as a U.S. business enterprise in which one foreign direct investor owns 10 percent or more of the voting securities or the equivalent.
} 
Figure 1. Value of FDI-Related Acquisitions in U.S. Energy and Annual Change in FDI Position in Petroleum and Coal, 1981-1993

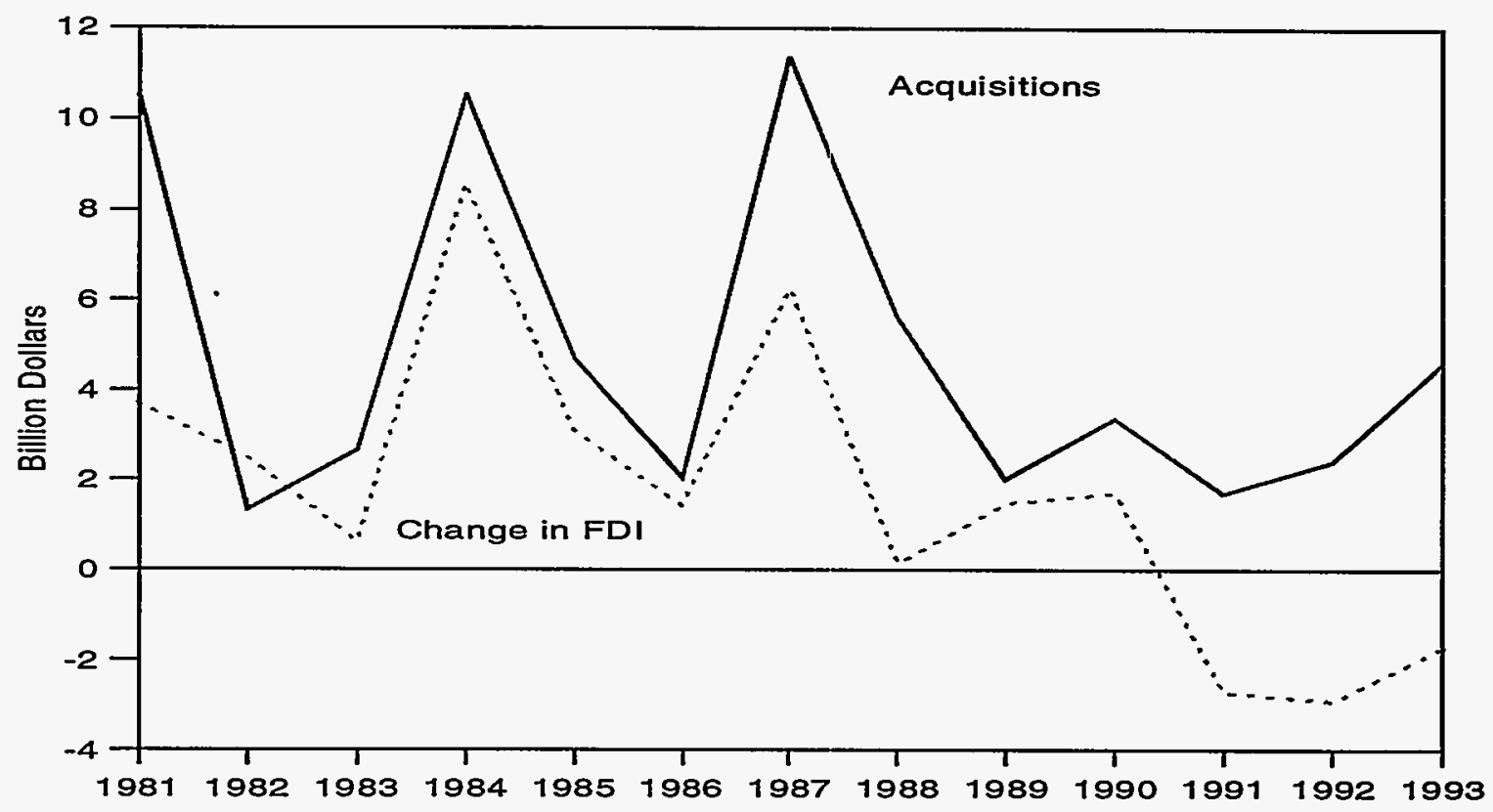

Sources: Value of FDl-related acquisitions: Tables $A 1, A 2$, and $A 3$ in the Appendix of this report and Tables $A 1, A 2$, and $A 3$ from previous editions of this report. Change in FDI: calculated as annual change in FDI position, based on latest consistent set of revisions, appearing in the August issues (1985-1994) of U.S. Department of Commerce, Bureau of Economic Analysis, Survey of Current Business.

subsidiary, acquired the U.S. coal mining company, Nerco, Inc., for $\$ 1.2$ billion, including Nerco's oil and gas assets (see the box entitled, Major FDI-Related Transactions in U.S. Energy). RTZ Corp. is an international mining company based in the United Kingdom, with operations in North America, Australasia, Europe, South America, and Southern Africa. RTZ Corp. mines various minerals, but its coal mining interests lie mainly in Australia and, now, in the United States. In 1993, RTZ also acquired Cordero mining from Sun Company for $\$ 121$ million. With the Nerco and Cordero acquisitions, RTZ's Kennecott subsidiary became the fifth largest producer of coal in the United States. ${ }^{7}$ The RTZ-Nerco transaction also involved U.S. oil and gas assets. In 1992, Nerco reported proved reserves of 10.4 million barrels of oil and 402 million cubic feet of natural gas. ${ }^{8}$ RTZ sold Nerco's oil and gas properties to Louisiana Land and Exploration Company for $\$ 354$ million. In turn, the Nerco/ Louisiana Land transaction represented the largest foreign divestiture of U.S. petroleum assets in 1993 (discussed more fully in the next section). ${ }^{9}$ The other large coal-related FDI transaction in 1993 involved two foreign-affiliated companies and therefore had little effect on the overall level of foreign-affiliated companies' investment base in U.S. coal. The U.K. company, Hanson plc, purchased the coal assets of Santa Fe Pacific Corp. for $\$ 425$ million. Ownership of Santa Fe Pacific Corp. includes both Canadian and French interests.

The prominence of coal as a target of foreign investors in 1993 appears to be part of a continuing trend in the 1990's. In each of the years 1990 through 1992, the largest FDI-related transaction in U.S. energy involved coal assets. In 1992, Shell Oil, the U.S. subsidiary of Royal Dutch/Shell Group, sold its coal production and marketing business to Zeigler Coal Holding Co. for $\$ 850$ million. In this transaction, Shell Oil gained a 25percent ownership share in Zeigler, thereby bringing Zeigler to the ranks of foreign-affiliated companies. In 1993, Zeigler Coal ranked as the fourth largest producer

\footnotetext{
${ }^{7}$ Mining Magazine, December 1994, Table 3.

${ }^{8}$ Nerco, Inc., Securities and Exchange Commission Form 10-K, p. 12.

${ }^{9}$ Louisiana Land \& Exploration, 1993 Annual Report, p. 6.
} 


\section{Major FDI-Related Transactions in U.S. Energy 1993}

\section{Acquisitions}

Britain's RTZ Corp. plc, through its Kennecott Corp. subsidiary, acquired Nerco, Inc.'s coal, oil, and natural gas production assets for $\$ 1,162$ million.

Shell Oil Co., a subsidiary of the Royal Dutch/Shell Group, teamed up with Mexico's Petroleos Mexicanos (Pemex) to jointly co-finance a \$1-billion upgrade of Shell's Deer Park, Texas, refinery. Although 1993 expenditures for this upgrade are unknown, the investment is expected to be completed by 1995.

French-affiliated Schlumberger bought out its joint venture partner in Dowell Schlumberger, an oil field services concern, for $\$ 675$ million.

British-based Hanson plc obtained coal production assets from Santa Fe Pacific Corp. in a swap for gold mining assets. Hanson reported a fair market value of $\$ 425$ million for the assets.

Consol Energy, jointly owned by DuPont and Germany's Rheinbraun AG, acquired Island Creek Coal from Occidental Petroleum. Occidental reported a benefit of $\$ 221$ million.

In other energy ventures, in July 1993, Transco sold its independent power company, Transco Energy Ventures Company (TEVCO), to National Power America Inc., a subsidiary of National Power plc, for $\$ 150$ million.

Castle Energy, affiliated with Germany's Metallgesellschaft, acquired Powerine Oil and its 49,000 barrel-per-day California refinery from Austrian-affiliated Sargent Holding Company for $\$ 145$ million.

French-affiliated Louis Dreyfus Natural Gas paid \$138 million to Parker \& Parsley for U.S. oil and gas properties.

RTZ Corp. acquired the U.S. coal producer, Cordero Mining Co., in a transaction costing RTZ $\$ 121$ million.

Citgo Petroleum Corp., a wholly-owned subsidiary of Petroleos de Venezuela (PDVSA), agreed that Citgo fund the enhancement of Lyondell Petrochemical Company's refinery in exchange for equity in a new company. Citgo's 1993 outlays for this joint venture totaled $\$ 119$ million.

Norcen Energy Resources of Canada bought six Gulf of Mexico oil and gas fields from Torch Energy Advisors Inc., for a reported $\$ 106$ million.

\section{Divestitures}

RTZ Corp's U.S. subsidiary, Kennecott, sold virtually all of Nerco's oil and gas properties to Louisiana Land and Exploration Co. for $\$ 354$ million. Nerco also sold $\$ 284$ million of other oil and gas production properties to Western Gas Resources.

British-owned BP America sold its 85,000 barrel-per-day Ferndale, Washington, refinery, along with retail marketing and terminal facilities, to Tosco for $\$ 175$ million. 
of U.S. coal. ${ }^{10}$ In 1991, RWE AG of Germany acquired a 50-percent ownership share of Consol Energy, which was formed from DuPont's Consolidation Coal unit, with DuPont retaining a 50-percent share. Consol Energy is the second largest producer of U.S. coal. In 1990, Peabody Holding Company, the largest U.S. coal producer, was acquired by Hanson plc of the United Kingdom for $\$ 1.2$ billion. ${ }^{11}$ Peabody has been the top U.S. coal producer for many years.

Since 1980, foreign-affiliated ownership of U.S. coal resources has grown considerably. In 1980, foreign affiliates' production of U.S. coal accounted for only 4 percent of total domestic production. By 1987, the foreign share had risen to 20 percent and to 28 percent in 1993. As a result of these transactions, of the top five producers of coal in the United States in 1993 only ARCO was not foreign-affiliated. ${ }^{12}$

Large acquisitions, made almost exclusively by European companies-primarily from the United Kingdom and Germany, underlay the trend. The interest of European investors in U.S. coal assets is motivated in part by the need for European coal companies to find alternative sources of coal supply as they downsize their own coal industries. As European nations comply with European Community mandates calling for the eventual elimination of national coal subsidies, a large portion of European coal production is expected to become uneconomical. Costly coal subsidies have in large measure been responsible for sustaining a European coal industry that is high cost and inefficient by world standards. It is estimated that domestic coal prices in Belgium and Germany have in recent years been three times the import price and, in Spain, two times the import price. ${ }^{13}$ In the United Kingdom, domestic coal has been estimated to cost 40 percent more than import prices. In 1991, these subsidies cost Europeans an estimated $\$ 17$ billion. $^{14}$ For several years, negotiations have taken place within the European Community to abolish these subsidies. It is expected that the European coal subsidies will probably end within 10 years. ${ }^{15}$
In FDI-related coal transactions of recent years, the selling company has frequently been a major U.S. petroleum company. Over the past 20 years, the interest of the 25 U.S. major energy companies, as represented by the companies included in the Energy Information Administration's Financial Reporting System (FRS), in coal rose steadily but has declined in recent years. ${ }^{16}$ In 1974, the FRS companies accounted for 14 percent of total U.S. coal production. By 1988, the FRS companies' share peaked at 30 percent, while by 1993, the FRS companies' share had fallen to 21 percent. Belowaverage profitability drove some majors to shed their coal assets. In only two years of the 1977-1993 period did the profitability of FRS companies' coal operations exceed the returns from petroleum operations. ${ }^{17}$ Although RTZ reported that its Kennecott subsidiary expects "significant economic benefits to be gained at these mines through optimization of equipment, personnel and administration, ${ }^{\prime 18}$ it remains unclear whether foreign companies will be able to realize greater rates of profitability from U.S. coal operations than did the U.S. majors.

\section{Oil and Gas Production Acquisitions and Divestitures}

In 1993, most of the upstream (oil and gas exploration and production) FDI-related transactions appeared to be motivated by the desire to consolidate oil and gas production operations in the current low oil price environment. The value of foreign affiliates' acquisitions of U.S. oil and gas production assets, at $\$ 1.2$ billion in 1993, continued at the generally low level that began after the oil price collapse of 1986 (Figure 2).

Retrenchment and consolidation were evident in the heightened level of oil and gas divestitures by foreignaffiliated companies. In 1993, the value of oil and gas asset sales was about twice the level of 1992 and only 25 percent less than the value of acquisitions. The RTZNerco transaction, though primarily directed toward

\footnotetext{
${ }^{10}$ Mining Magazine, December 1994, Table 3.

${ }^{11}$ Energy Information Administration, Profiles of Foreign Direct Investment in U.S. Energy 1991, DOE/EIA-0466(91) (Washington DC, April 1993).

${ }^{12}$ Mining Magazine, December 1994, Table 3.

${ }^{13}$ The Financial Times Limited, December 2, 1994.

${ }^{14}$ The Financial Times Limited, December 2, 1994.

${ }^{15}$ The Financial Times Limited, December 2, 1994.

${ }^{16}$ Energy Information Administration, Performance Profiles of Major Energy Producers 1993, DOE/ELA-0206(93) (Washington, DC, January 1995).

${ }^{17}$ Energy Information Administration, Performance Profiles of Major Energy Producers 1993, DOE/ELA-0206(93) (Washington, DC, January 1995), p. 104.

${ }^{18}$ The RTZ Corporation plc, Annual Report and Accounts 1993, p. 16.
} 
coal assets, had a noticeable effect on oil and gas divestiture activity as well. The oil and gas assets acquired in the Nerco deal were subsequently sold by RTZ to Louisiana Land and Exploration for \$354 million.

The largest upstream petroleum transaction by a foreign-affiliated company in 1993 was Schlumberger's acquisition of the remaining interest in its U.S. affiliate, Dowell Schlumberger, for $\$ 675$ million. Only two other FDI-related acquisitions of upstream assets exceeded $\$ 100$ million in 1993:

- French-affiliated Louis Dreyfus Natural Gas acquired oil and gas properties from Parker \& Parsley Petroleum for $\$ 138$ million.

- Norcen Energy Resources, a Canadian company, bought Gulf of Mexico oil and gas fields from Torch Energy Advisors for $\$ 106$ million.

However, in October 1993, BP America and Shell Oil, both foreign affiliates, announced that they would spend $\$ 1.2$ billion on developing the Mars Project, a deep-water oil and gas well in the Gulf of Mexico. ${ }^{19} \mathrm{In}$ future years, this transaction should make a sizable contribution to FDI in U.S. upstream petroleum as Mars is expected to start producing in late 1996.

\section{Refining/Marketing Acquisitions and Joint Ventures}

In 1993, foreign affiliates' acquisitions of U.S. downstream assets, totaling nearly $\$ 1.3$ billion, resumed a pace similar to that of the late 1980's (Figure 2). Shell Oil, the U.S. subsidiary of Royal Dutch/Shell, and Petroleos Mexicanos (Pemex) signed a memorandum of understanding involving Shell's 225,000 barrel-per-day Deer Park, Texas, refinery. Both companies are committed to spending $\$ 1$ billion to upgrade the Deer Park refinery. The upgrade is expected to be completed in 1995, which means much of the expenditure will occur after $1993 .{ }^{20}$ Under the agreement, Pemex is to supply the refinery with crude oil inputs while Shell will sell unleaded gasoline to Pemex.

Another large downstream FDI-related transaction in 1993 was in many ways similar to the Shell/Pemex deal. In this transaction again a Latin American state energy company, Petroleos de Venezuela (PDVSA), was involved. PDVSA, like Pemex, exports large volumes of heavy crude oil. PDVSA's wholly-owned U.S. subsidiary, Citgo Petroleum Corporation, and Lyondell Petrochemical Company, a partly-owned subsidiary of ARCO, agreed that Citgo would fund the enhancement of Lyondell's Houston, Texas refinery in exchange for equity in a newly-created company, Lyóndell-Citgo Refining Company, Ltd. As in the Shell/Pemex deal, this venture affords PDVSA a secure outlet for its crude oil while providing Lyondell with a secure source of feedstocks. In 1993, Citgo spent $\$ 119$ million on the deal and anticipates that Lyondell-Citgo will spend approximately $\$ 800$ million on a refinery enhancement project intended to increase the refinery's conversion capacity for heavy crude oil. ${ }^{21}$

One other downstream acquisition exceeded $\$ 100$ million in value in 1993. Castle Energy, affiliated with Metallgesellschaft of Germany, purchased a 49,000barrel-per-day California refinery from Sargent Holding Company, an affiliate of the Austrian state energy company, OMV, for $\$ 145$ million.

The heightened level of downstream divestitures of $\$ 822$ million was mainly a consequence of ownership changes between foreign affiliates. That is, in the Shell/Pemex and Castle/Sargent deals, refinery assets were transferred between foreign-affiliated companies and each was counted as both an acquisition and a divestiture. However, BP America, the North American affiliate of British Petroleum, significantly reduced its commitment to U.S. refining by selling its 85,000 barrelper-day Washington refinery and associated assets for $\$ 175$ million to Tosco. Through this transaction, BP America largely withdrew from U.S. West Coast petroleum product markets.

Many of the FDI-related downstream transactions in recent years were directed to rounding out interests originally developed in the late 1980's. During the 19851990 period, the total value of foreign acquisitions of downstream assets ranged from $\$ 1$ billion to $\$ 2$ billion annually (Figure 2). Beginning in 1986, most of the foreign acquisitions of U.S. downstream operations reflected the movement of Venezuelan and Saudi Arabian state energy companies into the U.S. market. Kuwait, Venezuela, and Saudi Arabia, who are all members of the Organization of Petroleum Exporting Countries (OPEC), acquired downstream petroleum assets in industrialized countries in order to integrate

\footnotetext{
${ }^{19}$ The Wall Street Journal, October 6, 1993, p. A4.

${ }^{20}$ Shell Oil Company, 1993 Annual Report, p. 14.

${ }^{21}$ Citgo Petroleum Corporation, 1993 Annual Report, p. 33.
} 
Figure 2. Value of FDI-Related Acquisitions by Energy Se!gment, 1981-1993

Integrated Petroleum

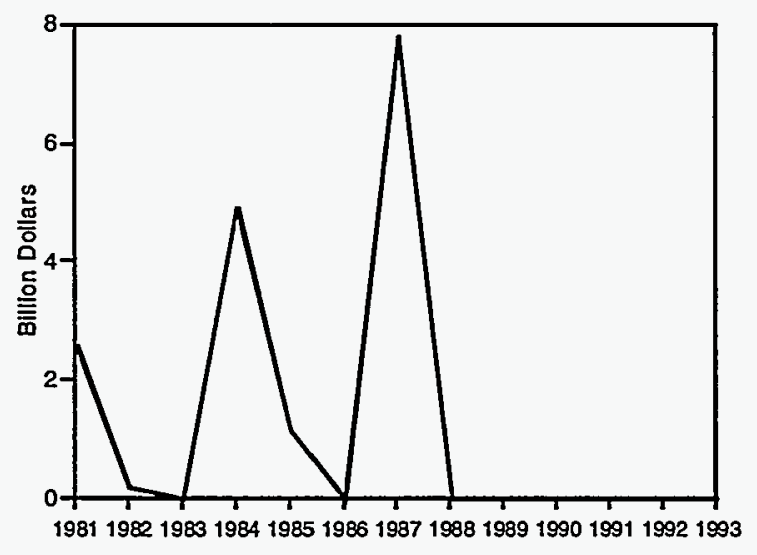

Downstream Petroleum

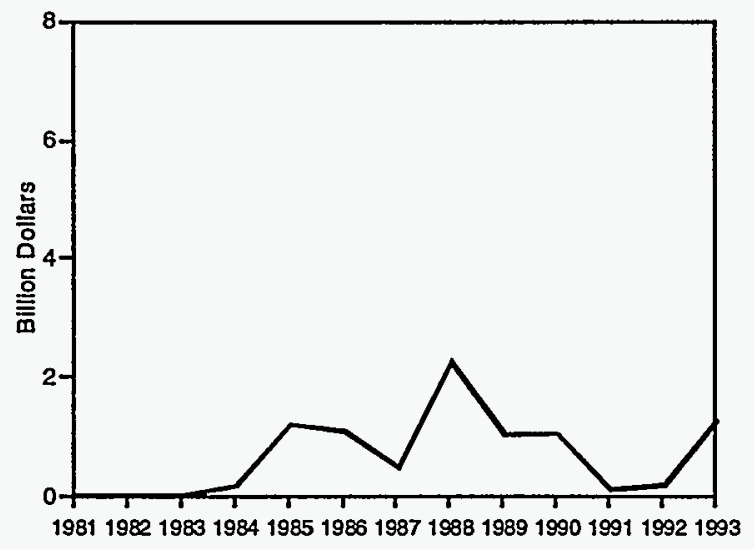

Exploration and Production

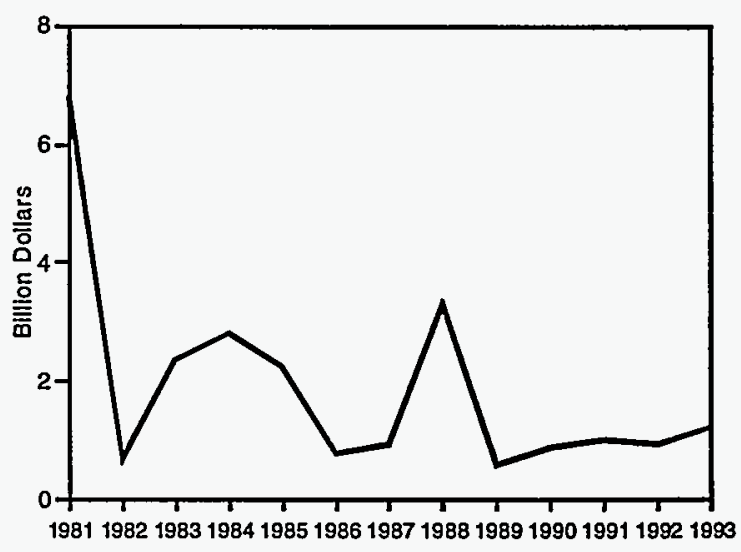

Coal and Other Energy

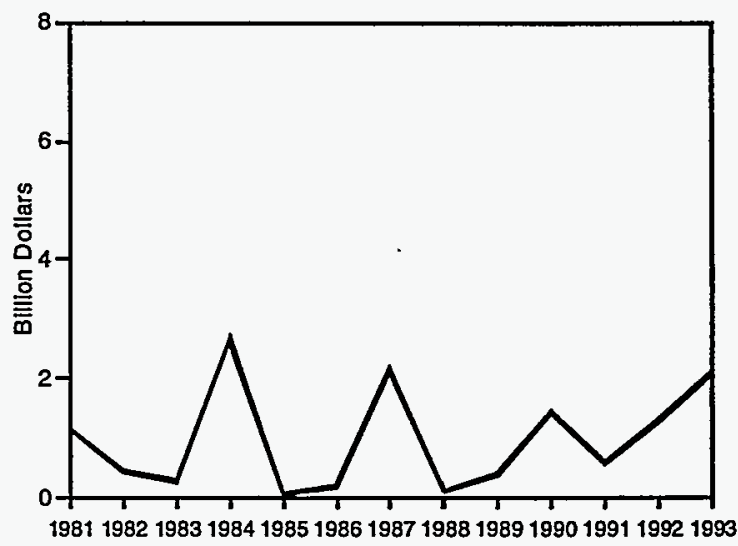

Sources: Tables $A 1, A 2$, and $A 3$ in the Appendix of this report and Tables $A 1, A 2$, and $A 3$ from previous editions of this report.

their oil production operations with petroleum refining and marketing (vertical integration). Vertical integration tends to moderate income fluctuations stemming from frequent, wide swings in the price of crude oil. Also, assured placement of oil production can be a benefit of vertical integration. During this period, Venezuela's PDVSA acquired Champlin Petroleum and its Texas refinery $(130,000$ barrels per day of crude distillation capacity) and Citgo Petroleum and its Louisiana refinery (305,000 barrels per day capacity). More recently, Seaview Petroleum, with a 44,000-barrel-per-day refinery in New Jersey, was added to the assets of Citgo Petroleum. PDVSA also developed a 50-percent partnership with Unocal Corporation in the Uno-Ven joint venture and its 147,000-barrel-per-day refinery in Illinois. In 1988, Saudi Arabia, through its Aramco subsidiary, formed the Star Enterprise joint venture with Texaco, which involved three refineries with a total capacity of 615,000 barrels per day. The share of U.S. refinery capacity associated with Venezuelan and Saudi Arabian interests rose from zero in 1985 to 8 percent in 1993 (reviewed in detail in Chapter 4). Their share of U.S. retail gasoline outlets rose from zero to 11 percent between 1985 and 1993. In total, foreignaffiliated companies owned 30 percent of U.S. refining capacity in 1993, and were responsible for nearly a third of all gasoline sales (see Chapter 4). 


\section{Patterns of Overall Foreign Direct Investment}

Overall additions to FDI in the United States rose to $\$ 19.6$ billion in 1993 from $\$ 6.9$ billion in 1992 (Table 2), when additions to FDI were at their lowest level since 1972. For the years 1988 through 1991, additions to FDI averaged $\$ 38$ billion per year. According to the U.S. Department of Commerce, the increase in foreign investment in 1993 was the result of:

... improvements in foreigners' incentive and ability to invest in the United States. Foreigners' incentive to invest was enhanced by the continued growth of the U.S. economy. Their ability to invest was strengthened by improved business conditions in certain major investor countries, such as the United Kingdom, which raised the earnings of the foreign parents in those countries. $^{22}$

Most of the 1993 additions were concentrated in the financial sector, including banking and insurance. The $\$ 8.9$ billion of additions to FDI in the financial services category was largely due to U.S. subsidiaries of British companies borrowing money from their parent companies (Table 2). Chemical operations were the main target of foreign investment among manufacturing industries. The largest FDI-related acquisition in 1993 involved the United Kingdom's Hanson plc's purchase of Quantum Chemical Corporation for $\$ 3.2$ billion.

Table 2. Targets of Foreign Direct Investment in U.S. Industry, 1991-1993 (Billion Dollars)

\begin{tabular}{|c|c|c|c|c|c|}
\hline \multirow[b]{2}{*}{ Industry } & \multicolumn{3}{|c|}{ Foreign Direct Investment Position } & \multicolumn{2}{|c|}{ Net Additions } \\
\hline & 1991 & 1992 & 1993 & 1992 & 1993 \\
\hline Total U.S. Industry & 418.8 & 425.6 & 445.3 & 6.9 & 19.6 \\
\hline 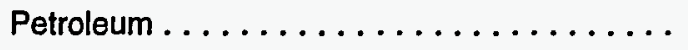 & 37.2 & 34.3 & 32.6 & -2.9 & -1.7 \\
\hline \multicolumn{6}{|l|}{ Manufacturing } \\
\hline Food \& Kindred Products . . . . . & 24.1 & 25.6 & 25.4 & 1.5 & -0.2 \\
\hline Chemicals \& Allied Products . . . . . . . . . . . & 51.1 & 53.7 & 57.7 & 2.5 & 4.0 \\
\hline Primary \& Fabricated Metals . . . . . . . . . . . & 13.3 & 12.9 & 13.0 & -0.4 & 0.1 \\
\hline 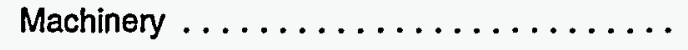 & 29.0 & 29.0 & 29.8 & 0.1 & 0.6 \\
\hline Other Manufacturing $\ldots \ldots \ldots$ & 41.1 & 42.0 & 40.9 & 1.0 & -1.1 \\
\hline \multicolumn{6}{|l|}{ Services } \\
\hline Wholesale Trade & 58.1 & 59.0 & 59.3 & 0.9 & 0.3 \\
\hline Retail Trade ... & 9.0 & 10.0 & 10.4 & 0.9 & 0.4 \\
\hline Banking.$\ldots \ldots \ldots \ldots \ldots \ldots \ldots$ & 24.3 & 26.3 & 31.0 & 2.0 & 4.7 \\
\hline Finance except Insurance . . . . . . . . . . & 17.4 & 17.7 & 26.5 & 0.3 & 8.9 \\
\hline Insurance $\ldots \ldots \ldots \ldots \ldots \ldots \ldots$ & 33.2 & 34.3 & 39.2 & 1.0 & 4.9 \\
\hline Real Estate $\ldots \ldots \ldots \ldots \ldots \ldots$ & 28.7 & 29.9 & 28.6 & 1.2 & -1.3 \\
\hline Other Services . .................. & 34.1 & 34.6 & 33.8 & 0.5 & -0.9 \\
\hline Other Industries $\ldots \ldots \ldots \ldots \ldots \ldots \ldots \ldots$ & 18.0 & 16.1 & 17.1 & -1.9 & 1.0 \\
\hline
\end{tabular}

Note: Sum of components may not equal total due to independent rounding.

Source: U.S. Department of Commerce, Bureau of Economic Analysis, Survey of Current Business (Washington, DC, August 1994).

${ }^{22}$ U.S. Department of Commerce, Bureau of Economic Analysis, Suroey of Current Business (Washington, DC, June 1994 ), p. 76. 
Other large manufacturing transactions included a $\$ 1.2-$ billion purchase of Sylvania Lighting by Siemens AG of Germany, a \$1.2-billion purchase of Packard Bell Electronics Inc. by France's Cie. des Machines Bull, and Japan's Asahi Glass Company's acquisition of AFG Industries for $\$ 1.0$ billion. Real estate, other manufacturing, other services, and food and kindred products were the only other industries to experience a decline in FDI besides petroleum. Only in the case of the Netherlands was an increase in FDI related to U.S. petroleum operations. The Shell-Pemex and Shell-BP America joint ventures, reviewed in Chapter 2, accounted for much of this increase.

Although Japan's economic recession resulted in a shrinkage of Japan's FDI position in the United States by $\$ 1.3$ billion, Japan retained its position as the number one FDI investor, followed by the United
Kingdom and the Netherlands (Table 3). In 1993, overall Japanese direct investment in the U.S. economy approached $\$ 100$ billion.

Despite the upturn in overall additions to FDI in 1993, FDI in U.S. petroleum operations continued to decline. Additions to FDI in U.S. petroleum were a negative $\$ 1.7$ billion in 1993 (Table 2). This compares to a negative $\$ 2.9$ billion in 1992 , which was the lowest level since at least 1981. Much of the decrease in FDI appears traceable to petroleum transactions involving BP America, the U.S. subsidiary of British Petroleum. In part, the substantial downstream divestiture of the Ferndale, Washington, refinery accounted for British Petroleum's reduced investment in 1993. In addition, payment of $\$ 630$ million to the State of Alaska to settle a back tax dispute also reduced the FDI position of British Petroleum in the United States. ${ }^{23}$

Table 3. Geographic Sources of Foreign Direct Investment in U.S. Industry, 1991-1993 (Billion Dollars)

\begin{tabular}{|c|c|c|c|c|c|}
\hline \multirow[b]{2}{*}{ Country } & \multicolumn{3}{|c|}{ Foreign Direct Investment Position } & \multicolumn{2}{|c|}{ Net Additions } \\
\hline & 1991 & 1992 & 1993 & 1992 & 1993 \\
\hline All Countries $\ldots \ldots \ldots \ldots \ldots \ldots \ldots$ & 418.8 & 425.6 & 445.3 & 6.9 & 19.6 \\
\hline Canada $\ldots \ldots \ldots \ldots \ldots \ldots$ & 36.3 & 37.8 & 39.4 & 1.5 & 1.6 \\
\hline \multicolumn{6}{|l|}{ Europe } \\
\hline United Kingdom $\ldots \ldots \ldots \ldots \ldots \ldots$ & 98.2 & 89.1 & 95.4 & -9.2 & 6.3 \\
\hline Netherlands .. & 59.8 & 65.3 & 68.5 & 5.5 & 3.2 \\
\hline Germany ......... & 28.6 & 29.6 & 34.7 & 1.0 & 5.1 \\
\hline Other Europe . . & 66.1 & 67.2 & 72.2 & 1.1 & 5.0 \\
\hline \multicolumn{6}{|l|}{ Latin America ${ }^{a}$} \\
\hline Netherlands Antilles & 7.8 & 8.6 & 7.0 & 0.8 & -1.6 \\
\hline Panama $\ldots \ldots \ldots \ldots \ldots \ldots$ & 4.8 & 5.0 & 4.7 & 0.2 & -0.3 \\
\hline Venezuela $\ldots \ldots \ldots \ldots \ldots \ldots$ & 0.5 & 0.4 & -0.4 & 0.0 & -0.8 \\
\hline Other Latin America $\ldots \ldots \ldots \ldots \ldots$ & 10.6 & 12.0 & 13.8 & 1.4 & 1.7 \\
\hline Australia ... . & 6.4 & 7.1 & 7.3 & 0.7 & 0.2 \\
\hline Other OPEC ${ }^{b}$ & 3.4 & 3.5 & 3.4 & 0.1 & -0.2 \\
\hline Japan ....... & 93.8 & 97.5 & 96.2 & 3.8 & -1.3 \\
\hline Other Countries .... & 1.1 & 0.9 & 1.4 & -0.1 & 0.4 \\
\hline
\end{tabular}

a Latin America includes South America, Central America, and the Caribbean (outside of U.S. possessions and territories).

OPEC is the Organization of Petroleum Exporting Countries. Its members are Algeria, Ecuador, Gabon, Indonesia, Iraq, Kuwait, Libya, Nigeria, Qatar, Saudi Arabia, the United Arab Emirates, and Venezuela.

Note: Sum of components may not equal total due to independent rounding.

Source: U.S. Department of Commerce, Bureau of Economic Analysis, Survey of Current Business (Washington, DC, August 1994).

\footnotetext{
${ }^{23}$ The British Petroleum Company, p.l.c., Annual Report on Form 20-F 1993, p. 45.
} 
In 1993, the petroleum industry's share of overall FDI in the United States, at 7 percent, was at a historical low and roughly half the level of a decade ago (Table 4). Since 1986, sharply lower oil prices have reduced the attractiveness of upstream petroleum (oil and gas exploration and production) investment. However, the decline in petroleum's share of total FDI in the United States has also been due to the greater growth in FDI in other industries, which more than doubled between 1986 and 1993.

Although Japan and Germany are important sources of overall FDI in the United States (Germany being the fifth largest source of overall FDI in the United States (Table 3)), these two nations' ownership of U.S. petroleum assets is small (Table 5). Most FDI in U.S petroleum comes from the Netherlands ( 38 percent) and the United Kingdom (29 percent). While the United
Kingdom's FDI position in U.S. petroleum is largely represented by BP America (the U.S. subsidiary of the British Petroleum Company plc), Shell Oil Company (a subsidiary of the Royal Dutch/Shell Group) accounts for most of the Netherland's investment in U.S. petroleum. Other European nations were responsible for roughly 10 percent of U.S. petroleum industry FDI in 1993. France's two largest petroleum companies, Elf Aquitaine and Total, along with Belgium's largest petroleum company Petrofina, accounted for nearly all of the other European investment.

Canadian investors' interest in U.S. petroleum operations, until recently, was in a long-term decline, beginning in 1981. The Canadian share of petroleumrelated FDI was 15 percent in 1980, fell to 9 percent in 1982 , and steadily declined to 3 percent in $1990 .{ }^{24}$ The decline was initially due to Canadian government

Table 4. Foreign Direct Investment in U.S. Petroleum and Coal, 1980-1993

\begin{tabular}{|c|c|c|c|c|c|c|}
\hline & & $\begin{array}{l}\text { Foreign Direct } \\
\text { Investment } \\
\text { in U.S. } \\
\text { Petroleum }^{\mathrm{a}, \mathrm{b}} \\
\text { (billion dollars) }\end{array}$ & $\begin{array}{l}\text { Foreign Direct } \\
\text { Investment } \\
\text { in U.S. Coal } \\
\text { (billion dollars) }\end{array}$ & $\begin{array}{l}\text { Total } \\
\text { Foreign Direct } \\
\text { Investment } \\
\text { in the U.S. } \\
\text { (billion dollars) }\end{array}$ & $\begin{array}{c}\text { Petroleum } \\
\text { as a Percent } \\
\text { of Total }\end{array}$ & $\begin{array}{c}\text { Coal as a } \\
\text { Percent of } \\
\text { Total }\end{array}$ \\
\hline 1980 & $\ldots \ldots \ldots \ldots \ldots$ & 12.2 & 0.5 & 83.0 & 14.7 & 0.6 \\
\hline 1981 & $\ldots \ldots \ldots \ldots \ldots$ & 15.2 & 1.1 & 108.7 & 14.0 & 1.0 \\
\hline 1982 & $\ldots \ldots \ldots \ldots \ldots$ & 17.7 & 1.2 & 124.7 & 14.2 & 1.0 \\
\hline 1983 & $\ldots \ldots \ldots \ldots \ldots$ & 18.2 & 1.3 & 137.1 & 13.3 & 0.9 \\
\hline 1984 & $\ldots \ldots \ldots \ldots \ldots$ & 25.4 & 2.6 & 164.6 & 15.4 & 1.6 \\
\hline 1985 & $\ldots \ldots \ldots \ldots \ldots$ & 28.3 & 2.9 & 184.6 & 15.3 & 1.6 \\
\hline 1986 & $\ldots \ldots \ldots \ldots \ldots \ldots$ & 29.1 & 3.5 & 220.4 & 13.2 & 1.6 \\
\hline 1987 & $\ldots \ldots \ldots \ldots \ldots$ & 37.8 & 3.3 & 263.4 & 14.4 & 1.3 \\
\hline 1988 & $\ldots \ldots \ldots \ldots \ldots$ & 36.0 & 5.3 & 314.8 & 11.4 & 1.7 \\
\hline 1989 & $\ldots \ldots \ldots \ldots \ldots$ & 40.3 & 0.9 & 368.9 & 10.9 & 0.2 \\
\hline 1990 & $\ldots \ldots \ldots \ldots \ldots$ & 42.9 & 0.8 & 394.9 & 10.9 & 0.2 \\
\hline 1991 & $\ldots \ldots \ldots \ldots \ldots$ & 37.2 & 1.3 & 418.8 & 8.9 & 0.3 \\
\hline 1992 & $\ldots \ldots \ldots \ldots \ldots$ & 34.3 & 1.5 & 425.6 & 8.1 & 0.4 \\
\hline 1993 & 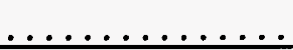 & 32.6 & 1.5 & 445.3 & 7.3 & 0.3 \\
\hline
\end{tabular}

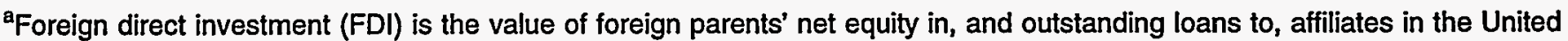
States at the end of the year.

The petroleum industry includes all phases of oil and gas exploration and production, petroleum refining, petroleum transport, and petroleum marketing.

Sources: 1991-1993: U.S. Department of Commerce, Bureau of Economic Analysis, Survey of Current Business (Washington, DC, August 1994). 1987-1990: U.S. Department of Commerce, Bureau of Economic Analysis, Survey of Current Business (Washington, DC, August 1993). 1985-1986: U.S. Department of Commerce, Bureau of Economic Analysis, Survey of Current Business (Washington, DC, August 1990). 1981-1984: U.S. Department of Commerce, Bureau of Economic Analysis, Survey of Current Business (Washington, DC, August 1986). 1980: U.S. Department of Commerce, Bureau of Economic Analysis, Survey of Current Business (Washington, DC, October 1984).

\footnotetext{
${ }^{24}$ Energy Information Administration, Foreign Direct Investment in U.S. Energy 1991, DOE/EIA-0466(91) (Washington, DC, April 1993), and earlier editions.
} 
policies favoring Canadian ownership of energy resources located in Canada. This policy encouraged Canadians to invest in Canadian energy resources, apparently at the expense of U.S. petroleum investments. In addition, in the mid-1980's, the Canadian government relaxed and eventually eliminated most energy price controls and reduced taxes related to oil and gas. More recently, restrictions on the export of Canadian natural gas were relaxed, resulting in an additional incentive for Canadians to invest in their own oil and gas resources. However, Toronto-based Horsham Corporation's acquisition of Clark Refining and Marketing Inc. increased Canadian investment in U.S. downstream. Upstream, minority interests owned by Canadians in Santa Fe Energy and continued growth in U.S. oil and gas production by Norcen Energy Resources and Chieftain International have added to Canadian investment.

Based on the U.S. Department of Commerce's data, FDI in the U.S. coal industry appears small and static in recent years (Table 4). For the analysis of coal-related FDI, the U.S. Department of Commerce's classification procedure causes problems. ${ }^{25}$ Due to the relatively

Table 5. Geographic Sources of Foreign Direct Investment in U.S. Petroleum, 1991-1993

\begin{tabular}{|c|c|c|c|c|c|c|}
\hline Source & 1991 & 1992 & 1993 & 1991 & 1992 & 1993 \\
\hline & \multicolumn{3}{|c|}{ (millions of dollars) } & \multicolumn{3}{|c|}{ (percent of total) } \\
\hline All Countries .......... & 37,222 & 34,347 & 32,647 & 100.0 & 100.0 & 100.0 \\
\hline Canada & 1,511 & 1,649 & 1,991 & 4.1 & 4.8 & 6.1 \\
\hline \multicolumn{7}{|l|}{ Europe } \\
\hline United Kingdom . . . . . . . & 13,980 & 10,901 & 9,367 & 37.6 & 31.7 & 28.7 \\
\hline Netherlands ... & 12,422 & 11,783 & 12,424 & 33.4 & 34.3 & 38.1 \\
\hline Germany .... & 216 & 664 & (b) & 0.6 & 1.9 & (b) \\
\hline Other Europe $\ldots \ldots \ldots$ & 2,172 & 2,658 & (D) & 5.8 & 7.7 & (b) \\
\hline \multicolumn{7}{|l|}{ Latin America ${ }^{\mathrm{a}}$} \\
\hline Netherlands Antilles . . . . . & 1,422 & 1,480 & 1,593 & 3.8 & 4.3 & 4.9 \\
\hline Venezuela .......... & 390 & $\left(b^{b}\right)$ & $(\mathrm{b})$ & 1.0 & $($ (b) & (b) \\
\hline Other Latin America & 639 & 808 & -357 & 1.7 & 2.4 & -1.1 \\
\hline Australia . . . . . . . . . & 2,464 & 2,493 & 2,513 & 6.6 & 7.3 & 7.7 \\
\hline Other OPEC ${ }^{c}$ & 1,623 & (b) & $\left({ }^{b}\right)$ & 4.4 & (b) & (b) \\
\hline Japan ............ & 150 & 140 & 254 & 0.4 & 0.4 & 0.8 \\
\hline Other Countries $\ldots \ldots \ldots$ & 233 & (b) & $\left({ }^{b}\right)$ & 0.6 & (b) & (b) \\
\hline
\end{tabular}

aLatin America includes South America, Central America, and the Caribbean (outside of U.S. possessions and territories).

${ }^{b}$ Data withheld by the U.S. Department of Commerce to prevent disclosure. Venezuela is included in Other Latin America in 1992 and 1993.

'OPEC is the Organization of Petroleum Exporting Countries. Its members are Algeria, Ecuador, Gabon, Indonesia, Iran, Iraq, Kuwait, Libya, Nigeria, Qatar, Saudi Arabia, the United Arab Emirates, and Venezuela.

Source: U.S Department of Commerce, Bureau of Economic Analysis, Survey of Current Business (Washington, DC, August 1994).

\footnotetext{
${ }^{25}$ Three limitations of the U.S. Department of Commerce data can pose difficulties in assessing targets of investment among foreign investors. First, revisions of industry classifications of foreign-affiliated U.S. companies are made for only the most recent years. For example, in the data for 1993, revisions were made retroactive through 1991. Consequently, the change in FDI position between 1990 and 1991 is, to some unknown extent, due solely to industry reclassifications. Second, the industry classifications of foreign-affiliated companies may ascribe significant energy investment activity to nonenergy industries. For example, the highly diversified Hanson plc acquired 100 percent of Peabody Holding Company (the leading producer of U.S. coal) in 1990 for $\$ 1.2$ billion. However, the effect on FDI of this acquisition appears to have been classified to an industry other than coal. Third, FDI measures net financial flows between parent and U.S. subsidiary, which can obscure the interpretation of FDI statistics. For example, a large repayment in the reporting year to a parent company of debt incurred in an earlier acquisition can reduce FDI even though FDI-related acquisition activity may have increased substantially in the reporting year.
} 
large ownership of U.S. coal resources by foreign conglomerates such as Hanson and RTZ, whose primary industry classifications are in businesses other than coal mining, the FDI data understate the growing foreign presence in U.S. coal mining in recent years. To gauge the foreign affiliates' trend in U.S. coal mining investment, it is necessary to look at the number and value of individual coal-related transactions, as profiled in Chapter 2.

\section{Outward Investment in Petroleum}

Investment flows out of the United States as well as into the United States. Direct investment abroad (DIA), which is also reported by the U.S. Department of Commerce, is the value of U.S. parent companies' net equity in, and loans to, affiliates outside the United States. The DIA position in petroleum operations abroad, relative to total DIA in all industries, peaked at 28 percent in the 1982-1984 period (Table 6). Since then, the value of the DIA position in petroleum has increased less than 10 percent. However, DIA outside petroleum more than tripled since 1984 as U.S. corporations responded to opportunities and competitive pressures stemming from growth in international trade. ${ }^{26}$ As a result, petroleum-related DIA was only 11 percent of total DIA in 1993.

Although petroleum's share of overall direct investment abroad fell to 11 percent in 1993, the lowest level since at least 1974, overall U.S. direct investment in foreign petroleum operations rose by nearly $\$ 5$ billion between 1992 and 1993 (Table 6). However, direct investment abroad measures only the net flow of funds between U.S. companies and their foreign-based affiliates. A positive change in this measure does not necessarily indicate a greater level of capital expenditures by U.S. companies abroad nor does a negative change always indicate a diminished interest in foreign petroleum operations. For petroleum companies, capital and exploratory expenditures are a more direct reflection of U.S. companies' targets of investment abroad. Fortunately, the Energy Information Administration's Financial Reporting System (FRS) provides regional and

Table 6. U.S. Direct Investment in Foreign Petroleum, 1980-1993

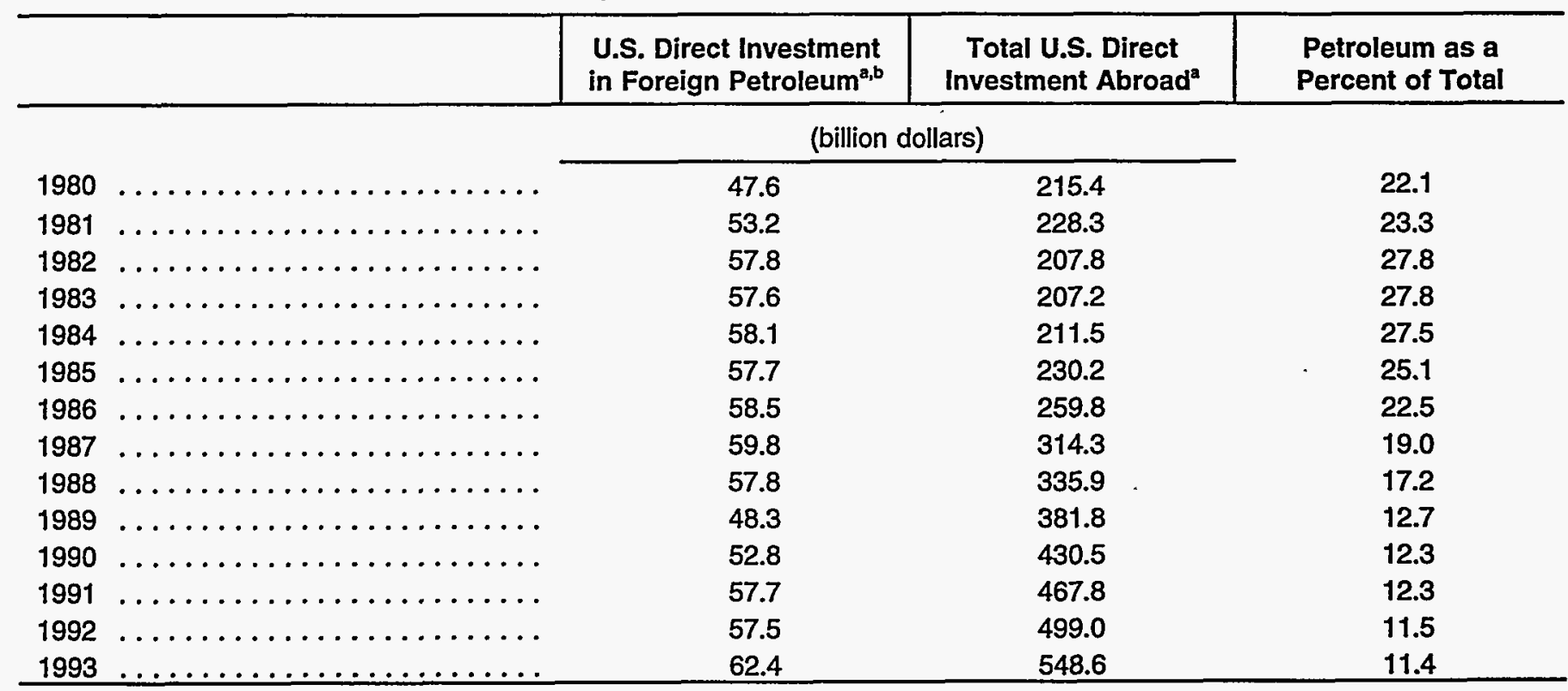

aDirect Investment Abroad is the value of U.S. parents' net equity in, and outstanding loans to, affiliates outside the United States.

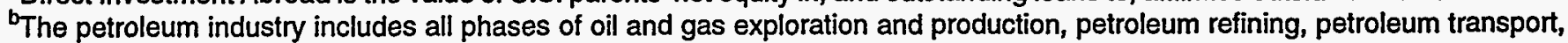
and petroleum marketing.

Sources: 1989-1993: U.S. Department of Commerce, Bureau of Economic Analysis, Sunvey of Current Business (Washington, DC, August 1994). 1987-1988: U.S. Department of Commerce, Bureau of Economic Analysis, Survey of Current Business (Washington, DC, August 1993). 1985-1986: U.S. Department of Commerce, Bureau of Economic Analysis, Survey of Current Business (Washington, DC, August 1990). 1982-1984: U.S. Department of Commerce, Bureau of Economic Analysis, Survey of Current Business (Washington, DC, August 1987). 1980-1981: U.S. Department of Commerce, Bureau of Economic Analysis, Survey of Current Business (Washington, DC, August 1985).

${ }^{26}$ U.S. Department of Commerce, Bureau of Economic Analysis, Survey of Current Business (Washington, DC, July 1993), pp. 65-67 and 83-85. 
line-of-business disaggregations of capital and exploratory expenditures. In 1993, the 25 major energy companies reporting to the FRS accounted for nearly 90 percent of U.S. companies' foreign petroleum expenditures. ${ }^{27}$

Following the oil price collapse of 1986, the FRS companies increasingly shifted their upstream expenditures to foreign locales. Between 1986 and 1991, foreign exploration and development (E\&D) expenditures nearly doubled while U.S. expenditures fell by 10 percent (Figure 3). By 1991, the FRS companies' foreign exploration and development expenditures exceeded U.S. expenditures, as they have continued to do so far through the 1990's. In the first years following the oil price collapse, the attractiveness of foreign upstream investment targets appeared to reflect differences in profitability. For the $1986-1989$ period, the profitability of the FRS companies' foreign oil and gas production operations averaged nearly 8 percentage points more than U.S. operations. ${ }^{28}$ However, differences in profitability have narrowed as capital moved abroad and U.S. operations were consolidated. In 1992 and 1993, the difference in upstream profitability averaged only 3 percentage points. A variety of additional factors contributed to the shift in exploration

Figure 3. Exploration and Development Expenditures of the FRS Companies, 1981-1993

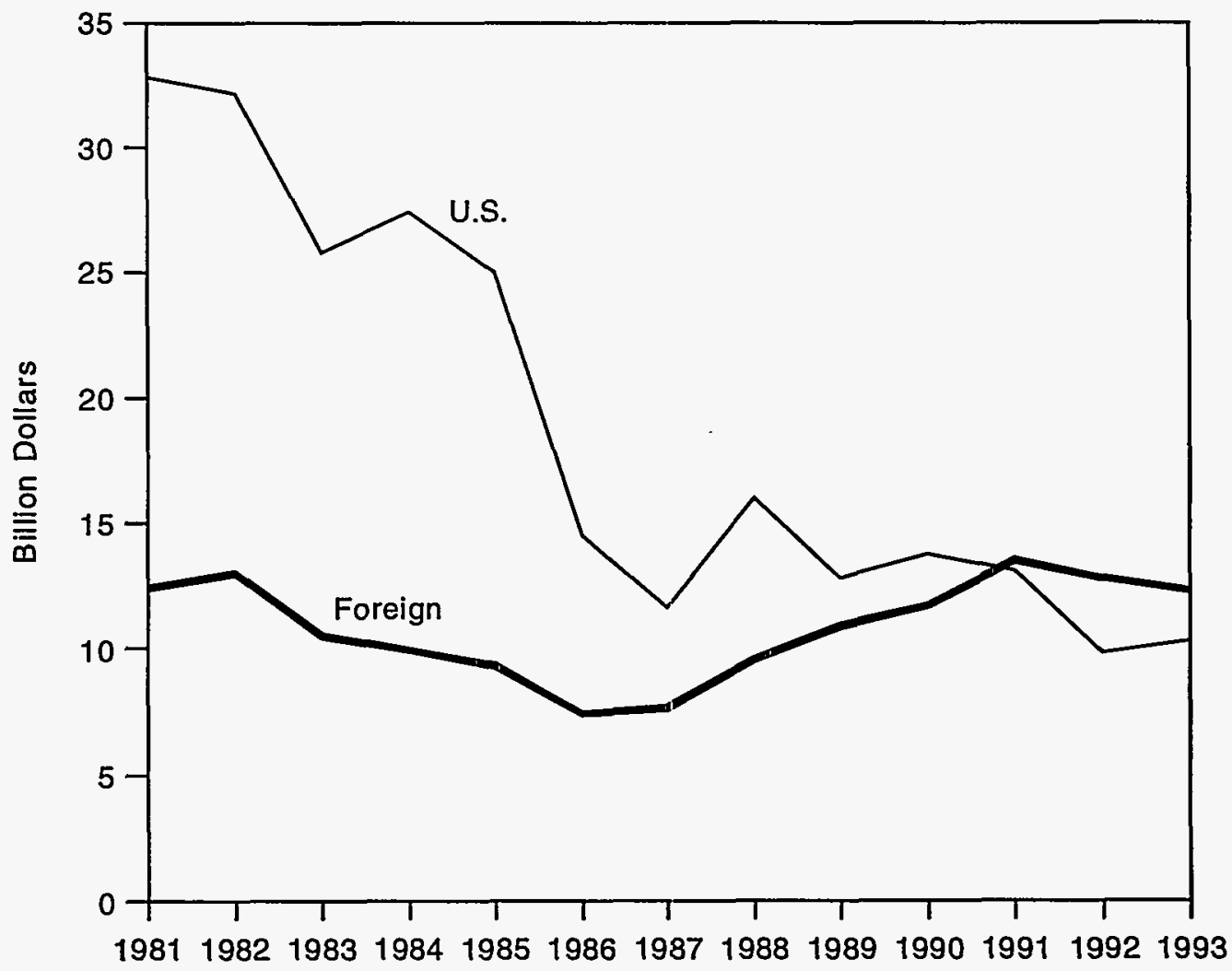

Note: Excludes expenditures for proved acreage.

Source: Energy Information Administration, Performance Profiles of Major Energy Producers 1993, DOE/EIA-0206(93) (Washington, DC, January 1995).

\footnotetext{
${ }^{n}$ Overall foreign investment of the majors was obtained from the Energy Information Administration's Performance Profiles of Major Energy Producers 1993, DOE/EIA-0206(93) (Washington DC, January 1995), Table B11, and the U.S. Department of Commerce's Survey of Current Business, March 1994, p. 37.

${ }^{28}$ Energy Information Administration, Performance Profiles of Major Energy Producers 1993, DOE/EIA-0206(93) (Washington, DC, January 1995), Table 3.
} 
and development expenditures to locales outside North America. These factors, which have been reviewed extensively elsewhere, include the interactions of costs, geology, development of natural gas markets, regulations, and tax policies. ${ }^{29}$ Excluding the effects of acquisitions, the increase in E\&D spending was mostly directed to Europe and Southeast Asia. Investments in Europe accounted for over half the increase in FRS foreign E\&D spending over the 1986-1991 period (Figure 4). These investments were largely directed toward exploring and developing oil and gas prospects in the North Sea. The Other Eastern Hemisphere region accounted for 20 percent of the total increase in FRS foreign E\&D spending between 1986 and 1991. The increase in E\&D spending in Canada between 1986 and 1991 was largely concentrated in companies that made significant acquisitions of Canadian assets in the late 1980 's.

Following the war-induced runup in oil prices in the latter months of 1990, lower crude oil prices again reduced the profitability of upstream investments, both at home and abroad. In real terms, oil prices in 1993 were actually lower than their 1986 levels. This decline resulted in a reduction in E\&D expenditures. Exploration bore the brunt of the decline in total foreign E\&D, while development expenditures increased or remained stable in most regions. In the context of low oil prices, companies in recent years have shied away from aggressive, risky exploration programs, favoring more secure development projects, which usually have quicker payouts.

Figure 4. Exploration and Development Expenditures, by Region, for FRS Companies, 1986, 1991, and 1993

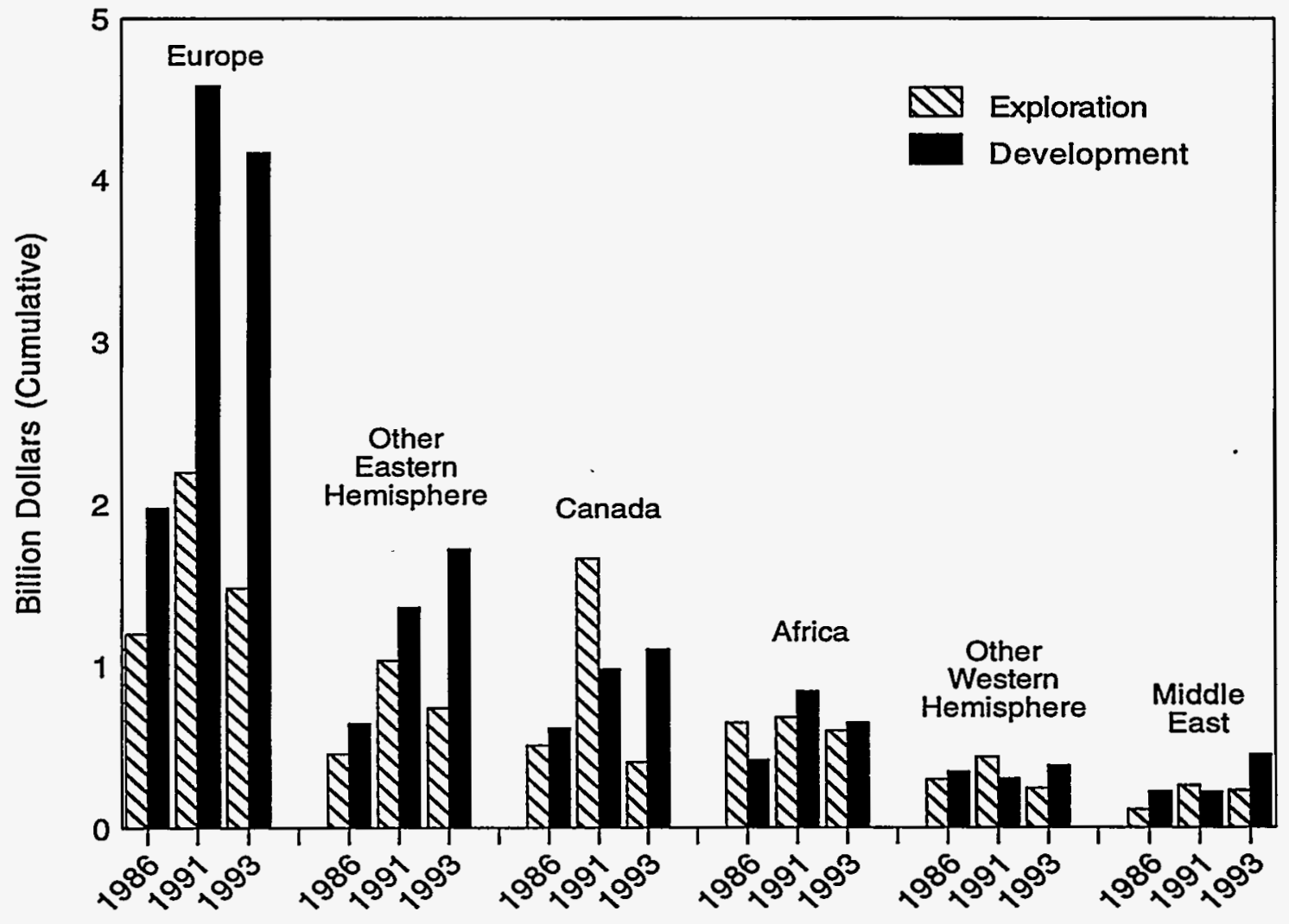

Note: Excludes expenditures for proved acreage.

Source: Energy Information Administration, Form EIA-28.

\footnotetext{
${ }^{29}$ Energy Information Administration, Performance Profiles of Major Energy Producers 1991, DOE/EIA-0206(91) (Washington, DC, December 1992), pp. 22-24.
} 
Foreign refining and marketing operations are also investment targets, but only for a minority of the FRS companies. The FRS companies' commitment to foreign refining stabilized in 1986, after a long-running retrenchment that began with the escalation of petroleum prices in the mid-1970's. The FRS companies reduced their refinery capacity outside the United States from 9.3 million barrels per day in 1974 to 4.6 million barrels per day in $19866^{30}$

Despite the reduction in capacity, investment in FRS foreign refining operations has grown steadily. Much of this investment has been directed toward upgrading refineries to produce more gasoline, diesel, and other light products. Although basic distillation capacity remained at 4.6 million barrels per day in 1993, production of lighter end products (gasoline and distillates) was up 16 percent over the 1986-1993 period. $^{31}$ Capital expenditures for foreign refining and marketing totaled $\$ 2.1$ billion in 1986, but generally increased thereafter. ${ }^{32}$ After reaching a peak of $\$ 3.9$ billion in 1991, capital expenditures for foreign refining and marketing were $\$ 3.3$ billion in $1993 .{ }^{33}$ In part, the foreign expenditures have been driven by the same developments affecting spending in the United States. Producing higher-end products in a more environmentally benign manner accounts for some of the spending rise and has been evident in the growing levels of foreign refinery complexity and increasing levels of higher-end product outputs. A growing reliance on lower quality crude oil inputs has also produced a need for more capital investment in refinery conversion capacity.

The FRS companies reduced their level of foreign downstream capital expenditures to $\$ 3.3$ billion in 1993 from $\$ 3.6$ billion in 1992. Nevertheless, some companies reported undertaking significant investments. For example, in Europe, DuPont made a major acquisition of German gasoline marketing operations. ${ }^{34}$

Although the Southeast Asia and Pacific Basin region accounts for a lesser share of FRS investment in foreign downstream than does Europe, this region has become a rapidly growing area for investment in recent years. In part, this trend reflects Asia's rapid rate of product consumption growth-nearly three times the U.S. and world average. Japan is the largest target of U.S. refining/marketing investment in Asia, followed by Singapore. Four U.S. companies (Chevron, Exxon, Mobil, and Texaco) accounted for approximately one seventh of the ownership of Japanese refining capacity and one-half that of Singapore. For Chevron and Texaco, ownership of Asian refining is held through their joint venture, Caltex. In Japan, investment has been concentrated in increasing higher-end yields and increasing diesel hydrotreating and desulfurization capacity to produce lower sulfur fuels. ${ }^{35}$ In Singapore, investments were directed toward increasing low sulfur fuel capacity along with oxygenated unleaded gasoline capacity. Caltex is in the process of increasing its refining capacity in Singapore by 60,000 barrels per day.

In 1993, the FRS companies were involved in major downstream investments in other Asian nations as well. Caltex was in the process of upgrading its 50-percent owned 380,000 barrel-per-day Yocheon, Korea, refinery, ${ }^{36}$ while Exxon's expansion of its Sriracha, Thailand, refinery proceeded in 1993. Exxon estimates that the investment will cost $\$ 960$ million and add 70,000 barrels per day of capacity. Over the last 10 years, Thailand's demand for petroleum products has more than doubled. ${ }^{37}$

\footnotetext{
${ }^{30}$ Energy Information Administration, Performance Profiles of Major Energy Producers 1993, DOE/EIA-0206(93) (Washington, DC, January 1995).

${ }^{31}$ Energy Information Administration, Performance Profiles of Major Energy Producers 1993, DOE/EIA-0206(93) (Washington, DC, January 1995).

${ }^{32}$ Energy Information Administration, Performance Profiles of Major Energy Producers 1993, DOE/ELA-0206(93) (Washington, DC, January 1995).

${ }^{33}$ Energy Information Administration, Performance Profiles of Major Energy Producers 1993, DOE/EIA-0206(93) (Washington, DC, January 1995).

${ }^{34}$ DuPont, 1993 Annual Report, p. 25.

${ }^{35}$ Chevron Corporation, Supplement to the Chevron Corporation 1993 Annual Report, p. 43; Mobil Corporation, 1993 Mobil Fact Book, A Supplement to the Annual Report, p. 57; and, Texaco Inc., Financial and Operational Supplement 1993, p. 31.

${ }^{36}$ Chevron Corporation, 1993 Annual Report, p. 18.

${ }^{37}$ The British Petroleum Company, BP Statistical Review of World Energy, June 1994, p. 7.
} 


\section{The Role and Financial Performance of Foreign- Affiliated Companies in U.S. Energy Operations}

Transactions data and information drawn from the U.S. Department of Commerce's international investment surveys are useful in discerning the overall investment targets of foreign investors and the changing emphasis of their interest in U.S. energy. However, these data yield no information on the operational role of foreignaffiliated enterprises in U.S. energy activities in 1993, or over time. In this chapter, the involvement of foreignaffiliated companies in the areas of upstream and downstream petroleum operations (including natural gas production), coal production, and uranium exploration and development are reviewed. Generally, the involvement of foreign-affiliated companies in U.S. energy activity increased in 1993. Between 1992 and 1993, foreign-affiliated companies increased their production of natural gas, coal, and refined products, although oil produced by foreign affiliates fell 7 percent (Table 7). The financial performance of foreign-affiliated companies improved slightly in 1993. However, mainly due to the disproportionate impact on foreign affiliates of a major coal strike, their financial results in 1993 trailed the financial performance of other U.S. energy companies and U.S. industry in general.

\section{Oil and Gas Reserves and Production}

Three companies-BP America, Shell Oil, and DuPontaccount for almost 90 percent of the foreign-affiliated companies' U.S. oil production. Foreign affiliates' U.S. oil (crude oil and natural gas liquids) production fell 98,000 barrels per day between 1992 and 1993 (Table 7), representing a 7-percent decline from 1992. Total U.S. production fell a lesser 2-percent between 1992 and 1993, and as a consequence, foreign affiliates' share of total U.S. crude oil production fell to 14.7 percent in 1993, from 15.5 percent in 1992. BP America accounted for almost three-fifths of the total decline in foreign affiliates' U.S. oil production. This decline was largely attributable to falling production from BP America's Prudhoe Bay field in Alaska. ${ }^{38}$ Prudhoe Bay production entered a mature phase during the late 1980 's, peaking in 1988. However, some of the natural decline has been abated with the introduction of two gas-handling systems in the early 1990's. Shell Oil accounted for most of the remaining decline in foreign affiliates' crude oil production. Shell reported that its 1993 production fell due to natural declines in its California fields and to oil and gas property sales. ${ }^{39}$

In contrast to oil, the foreign affiliates' share of natural gas production increased in 1993 (Table 7). Reflecting an improved U.S. natural gas market, several foreignaffiliated companies reported higher production in 1993. Natural gas prices in 1993 were 17 percent higher than in 1992.0 Shell reported additional production from the Gulf of Mexico and from new wells in south Texas, while Louis Dreyfus' acquisition of oil and gas properties in 1993 also added noticeably to foreign affiliates' production.

Foreign-affiliated companies' share of U.S. oil reserves was largely unchanged between 1992 and 1993 (Table 8). Although some companies reported substantial purchases of reserves, these purchases were largely offset by reserve sales reported by other foreign affiliates. In one transaction, BP America reported a 110-million-barrel increase in its U.S. oil reserves in part due to the purchase of DuPont interests on the North Slope of Alaska. In 1993, DuPont reported a 77-millionbarrel decline in its U.S. crude oil reserves. ${ }^{41}$ The natural gas reserves of foreign-affiliated companies were also largely unchanged from 1992.

\section{Refining and Gasoline Marketing}

Although there were a number of both downstream acquisitions and divestitures in 1993, on balance

\footnotetext{
${ }^{33}$ The British Petroleum Company, plc, Annual Report on Form 20-F 1993, p. 14.

${ }^{39}$ Shell Oil Company, 1993 Annual Report, p. 30.

${ }^{10}$ Energy Information Administration, Monthly Energy Review January 1995, DOE/EIA-0035(95/01) (Washington DC, January 1995), Table 9.11.

${ }^{11}$ DuPont, 1993 Annual Report, p. 58.
} 
Table 7. Net Production of Petroleum and Dry Natural Gas in the United States by Foreign-Affiliated U.S. Companies, 1991-1993

\begin{tabular}{|c|c|c|c|c|c|c|}
\hline \multirow[b]{2}{*}{ Company } & \multicolumn{3}{|c|}{$\begin{array}{l}\text { Crude Oil and Natural Gasi Liquids }{ }^{a} \\
\text { (thousand barrels per day) }\end{array}$} & \multicolumn{3}{|c|}{$\begin{array}{l}\text { Dry Natural Gas }{ }^{a} \\
\text { (billion cubic feet) }\end{array}$} \\
\hline & 1991 & 1992 & 1993 & 1991 & 1992 & 1993 \\
\hline BP America & 738.0 & 685.8 & 627.7 & ${ }^{b} 78.8$ & $b_{38.0}$ & ${ }^{b} 33.0$ \\
\hline Shell Oil Co ...... & 457.5 & 445.4 & 402.7 & 501.0 & 532.0 & 539.0 \\
\hline DuPont ........... & 120.5 & 112.0 & 109.6 & 276.0 & 279.0 & 305.0 \\
\hline Santa Fe Energy Resources ..... & 55.2 & 58.5 & 60.0 & 34.8 & 46.2 & 60.3 \\
\hline Anadarko Petroleum & 16.9 & 17.2 & 26.8 & 134.4 & 143.9 & 159.0 \\
\hline Fina $\ldots \ldots \ldots \ldots$ & 21.0 & 19.6 & 16.2 & 74.4 & 75.6 & 67.9 \\
\hline Pogo Producing Co. . . . . . . . . & NF & 9.9 & NF & NF & 40.6 & NF \\
\hline BHP Petroleum (Americas) $\ldots \ldots$ & 10.8 & 8.0 & 8.0 & 48.4 & 41.8 & 41.8 \\
\hline Canadian Occidental Ltd. . . . . . . & 0.0 & 0.0 & 7.7 & 0.0 & 0.0 & 21.0 \\
\hline Hondo Oil and Gas . . . . . . . . & 7.7 & 5.5 & 0.0 & 12.9 & 9.7 & 0.0 \\
\hline Adobe Resources Corp. . ....... & 6.4 & $\left({ }^{c}\right)$ & $(9)$ & 28.5 & $(9)$ & (c) \\
\hline Louis Dreyfus Natural Gas Co. . . . & 0.0 & 0.0 & 5.8 & 0.0 & 0.0 & 30.5 \\
\hline Elf Aquitaine Inc. . . . . . . . . & 5.5 & 5.4 & 5.4 & 27.6 & 28.1 & 28.1 \\
\hline Presidio Oil Co. . ........... & 7.7 & 5.1 & 3.9 & 23.3 & 19.4 & 15.3 \\
\hline Coho Resources..$\ldots \ldots \ldots \ldots$ & 3.5 & 4.4 & 5.0 & 0.6 & 0.9 & 0.5 \\
\hline Norcen Energy Resources . . . . . . . & 2.5 & 3.9 & 3.3 & 11.1 & 13.5 & 19.8 \\
\hline Bridge Oil (USA) . . . . . . . . . & 4.1 & 3.3 & 3.0 & 32.1 & 29.3 & 29.3 \\
\hline Total Minatome Corp . ......... & 3.2 & 3.2 & 2.8 & 37.6 & 31.2 & 28.2 \\
\hline Ultramar $^{d} \ldots \ldots \ldots \ldots \ldots$ & 2.7 & NF & NF & 6.0 & NF & NF \\
\hline Saba Petroleum Co. ......... & 0.0 & 0.0 & 1.6 & 0.0 & 0.0 & 1.1 \\
\hline Chieftain Development International & 1.5 & 1.5 & 1.8 & 10.1 & 12.5 & 17.6 \\
\hline Other Companies .......... & 3.9 & 3.3 & 3.8 & 22.2 & 26.3 & 47.5 \\
\hline Total Foreign-Affiliated . . . . . . & $1,468.6$ & $1,392.0$ & $1,294.5$ & $1,359.7$ & $1,368.0$ & $1,444.9$ \\
\hline Total United States .......... & $9,168.0$ & $8,996.0$ & $8,836.0$ & $17,698.0$ & $17,840.0$ & $18,419.0$ \\
\hline Percent Foreign-Affiliated . . . . . & 16.0 & 15.5 & 14.7 & 7.7 & 7.7 & 7.8 \\
\hline
\end{tabular}

anless otherwise noted, company production is net ownership interest production.

bexcludes natural gas consumed in Alaskan operations.

${ }^{c}$ Acquired by Santa Fe Energy Resources in 1992.

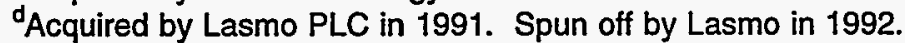

$\mathrm{NF}=$ No foreign affiliation during this period.

Note: Totals may not equal sum of components que to independent rounding.

Sources: Company data: Form 10-K reports to the U.S. Securities and Exchange Commission and Annual Reports to Shareholders. United States totals: Energy Information Administration, Monthly Energy Review, January 1995, DOE/EIA0035(95/01) (Washington, DC, January 1995).

foreign-affiliated companies increased their presence in U.S. refining and marketing. The foreign-affiliated companies' share of total U.S. crude distillation capacity rose from 28.1 percent in 1992 to 29.5 percent in 1993 or by 184,000 barrels per day (Table 9). Lyondell's 265,000 barrel-per-day Houston refinery entered the ranks of foreign-affiliated energy operations when Lyondell formed a joint venture with Citgo. Further, 28,000 barrels of capacity were added as a result of PDVSA's purchase of a Savannah, Georgia, asphalt refinery from Amoco Corp. These additions were in part offset by BP
America's sale of its 84,000 barrel-per-day Ferndale, Washington, refinery to Tosco Corp. One of the largest transactions in 1993 involved Shell's transfer of a 50percent interest in its Deer Park, Texas, refinery to its joint venture with Pemex. However, since this transaction involved two foreign-affiliated companies, it had no impact on the total share of FDI-related activity in U.S. refining.

The presence of foreign-affiliated companies in gasoline retailing grew slightly in 1993. In 1993, foreign-affiliated 
Table 8. Domestic Oil and Dry Natural Gas Proved Reserves and Production for Foreign-Affiliated U.S. Companies, 1992 and 1993

\begin{tabular}{|c|c|c|c|}
\hline Fuel Type & $\begin{array}{c}\text { Foreign-Affiliated } \\
\text { Companies }^{\mathrm{a}}\end{array}$ & U.S. Total & $\begin{array}{c}\text { Foreign-Affiliated Share } \\
\text { of U.S. Total } \\
\text { (percent) }\end{array}$ \\
\hline \multicolumn{4}{|l|}{ Crude Oll and Natural Gas } \\
\hline Liquids Proved Reserves & \multicolumn{2}{|c|}{ (million barrels) } & \\
\hline December 31, $1992 \ldots \ldots \ldots \ldots \ldots \ldots$ & 5,610 & 31,196 & 18.0 \\
\hline December $31,1993 \ldots \ldots \ldots \ldots \ldots$ & 5,627 & 30,179 & 18.6 \\
\hline 1993 Production $\ldots \ldots \ldots \ldots \ldots \ldots$ & 472 & 3,127 & 15.1 \\
\hline 1993 Gross Reserve Additions ${ }^{b} \ldots \ldots \ldots$ & 489 & 2,110 & 23.2 \\
\hline \multicolumn{4}{|l|}{1993 Ratio of Gross Reserve } \\
\hline \multirow[t]{2}{*}{ Additions to Production } & 1.04 & 0.67 & NM \\
\hline & \multicolumn{2}{|c|}{ (billion cubic feet) } & \\
\hline \multicolumn{4}{|l|}{ Dry Natural Gas Proved Reserves } \\
\hline December $31,1992 \ldots \ldots \ldots \ldots \ldots \ldots$ & 15,330 & 165,015 & 9.3 \\
\hline December 31, $1993 \ldots \ldots \ldots \ldots \ldots \ldots$ & 14,696 & 162,415 & 9.0 \\
\hline 1993 Production $\ldots \ldots \ldots \ldots \ldots \ldots$ & 1,445 & 17,789 & 8.1 \\
\hline 1993 Gross Reserve Additions ${ }^{b} \ldots \ldots \ldots$ & 811 & 15,189 & 5.3 \\
\hline \multicolumn{4}{|l|}{1993 Ratio of Gross Reserve } \\
\hline Additions to Production & 0.56 & 0.85 & NM \\
\hline
\end{tabular}

${ }^{a}$ Reserves and production are on a net ownership interest basis. The reserves and production data under each fuel type are for companies identified as foreign affiliated and reporting oil and/or natural gas production during 1993.

${ }^{b}$ Gross reserve additions = annual change in reserves + annual production.

$\mathrm{NM}=$ Not meaningful.

Sources: Foreign-affiliated data: Companies' Form 10-K filed with the U.S. Securities and Exchange Commission and annual reports to shareholders. U.S. totals: Energy Information Administration, U.S. Crude Oil, Natural Gas, and Natural Gas Liquids Reserves 1993 Annual Report, DOE/EIA-0216(93) (Washington, DC, September 1994).

companies operated over 50 thousand U.S. gasoline retail outlets-one-quarter of total U.S. outlets (Table 10). These same companies supplied 31 percent of the U.S. gasoline market. Both Citgo and Star Enterprise showed the largest increase in the number of service stations in operation. Measured by number of retail outlets, these companies ranked first and second in the United States in 1993. ${ }^{42}$ In 1993, Citgo's branded service stations increased by nearly 600 , while Star reported more than 400 additional stations.

\section{Coal Production}

The production of coal (bituminous and lignite) in the United States fell by 53 million tons in 1993, largely due to the United Mine Workers of America (UMWA) strike against selected coal mining companies and severe flooding in the Midwest (Table 11). The companies most affected by the strike operated primarily east of the Mississippi and were disproportionately foreignaffiliated. Despite the reduced level of production, coal prices were slightly lower in 1993 than in $1992 .{ }^{43}$ Even though lower coal prices and the coal strike worked to reduce the income of coal companies, foreign-affiliated companies increased their presence in the U.S. coal industry during 1993. Largely due to the U.S. coal mining acquisitions made by RTZ through its Kennecott subsidiary, foreign-affiliated companies increased their share of U.S. coal production from 26 percent in 1992 to 28 percent in 1993 (Table 11 and Figure 5).

\footnotetext{
${ }^{12}$ National Petroleum News, 1994 Fact Book, pp. 35-43.

${ }^{43}$ Energy Information Administration, Monthly Energy Review January 1995, DOE/EIA-0035(95/01) (Washington DC, January 1995), Tables 6.1 and 9.10 .
} 
Table 9. U.S. Refinery Operations of Foreign-Affiliated U.S. Companies, 1989-1993

\begin{tabular}{|c|c|c|c|c|c|c|c|c|c|c|}
\hline \multirow[b]{2}{*}{ Company } & \multicolumn{5}{|c|}{ Number of Refineries } & \multicolumn{5}{|c|}{$\begin{array}{l}\text { Total Crude Distillation Capacity } \\
\text { (thousand barrels per day) }\end{array}$} \\
\hline & 1989 & 1990 & 1991 & 1992 & 1993 & 1989 & 1990 & 1991 & 1992 & 1993 \\
\hline Shell Oil Co. ... & 7 & 7 & 6 & 6 & 5 & 1,079 & 1,083 & 967 & 973 & 739 \\
\hline BP America $\ldots \ldots \ldots$ & 5 & 5 & 5 & 5 & 4 & 757 & 734 & 741 & 747 & 666 \\
\hline Star Enterprise ...... & 3 & 3 & 3 & 3 & 3 & 615 & 615 & 615 & 615 & 600 \\
\hline Petroleos de Venezuela & $\left(b^{b}\right)$ & (b) & 3 & 3 & 4 & $(1)$ & ()$\left.^{b}\right)$ & 479 & 475 & 503 \\
\hline $\begin{array}{l}\text { DuPont.......... } \\
\text { Lyondell }\end{array}$ & 5 & 5 & 5 & 5 & 4 & 407 & 407 & 412 & 432 & 429 \\
\hline Petrochemical Co. ... & NF & NF & NF & NF & 1 & NF & NF & NF & NF & 265 \\
\hline Citgo Petroleum .... & 1 & 1 & $(b)$ & $(b)$ & (b) & 282 & 305 & $\left({ }^{b}\right)$ & (b) & ()$\left.^{\circ}\right)$ \\
\hline Shell OiV/PMI Holdings . & (d) & (d) & (d) & (d) & 1 & (d) & (d) & (d) & $\left({ }^{d}\right)$ & 216 \\
\hline Fina $\ldots \ldots \ldots \ldots$ & 2 & 2 & 2 & 2 & 2 & 165 & 165 & 199 & 199 & 199 \\
\hline Total Petroleum, Ltd. . . & 4 & 4 & 4 & 4 & 4 & 190 & 198 & 198 & 198 & 198 \\
\hline Uno-Ven.......... & 1 & 1 & 1 & 1 & 1 & 147 & 147 & 147 & 147 & 147 \\
\hline Champlin Refining Co. & 1 & 1 & (b) & (b) & (b) & 130 & 130 & (b) & (b) & (b) \\
\hline Clark Oil \& Refining . . & 2 & 2 & 2 & 2 & 2 & 122 & 122 & 122 & 122 & 129 \\
\hline Castle Energy . . . . . . & 0 & 1 & 1 & 1 & 2 & 0 & 55 & 55 & 69 & 120 \\
\hline \multicolumn{11}{|l|}{ BHP America's } \\
\hline Petroleum Refining Inc. & 1 & 1 & 1 & 1 & 1 & 79 & 94 & 94 & 94 & 94 \\
\hline Tesoro Petroleum .... & 1 & 1 & 1 & 1 & 1 & 72 & 72 & 72 & 72 & 72 \\
\hline American Ultramar Ltd. & 1 & 1 & 1 & NF & NF & 69 & 66 & 68 & NF & NF \\
\hline Pacific Refining . . . . . & 1 & 1 & 1 & 1 & 1 & 55 & 55 & 55 & 55 & 50 \\
\hline Sargent Holdings, Ltd. . & 1 & 1 & 1 & 1 & $\left({ }^{e}\right)$ & 44 & 45 & 45 & 45 & $\left({ }^{9}\right)$ \\
\hline Seaview Petroleum ... & NF & 1 & $\left({ }^{b}\right)$ & (b) & (b) & NF & 44 & (b) & (b) & (") \\
\hline Hondo Oil . . . . . . . . . & 1 & 1 & 1 & $(c)$ & (9) & 30 & 28 & 30 & $(9)$ & (c) \\
\hline Transworld Oil USA .. & 0 & 1 & 1 & 1 & 1 & 0 & 14 & 13 & 13 & 13 \\
\hline \multicolumn{11}{|l|}{ Total Foreign- } \\
\hline Affiliated $\ldots$ & 37 & 40 & 39 & 37 & 37 & 4,243 & 4,379 & 4,312 & 4,256 & 4,440 \\
\hline Total United States . . & 205 & 202 & 199 & 187 & 179 & 15,572 & 15,676 & 15,696 & 15,121 & 15,034 \\
\hline \multicolumn{11}{|l|}{ Percent Foreign- } \\
\hline Affiliated $\ldots \ldots \ldots$ & 18.0 & 19.8 & 19.6 & 19.8 & 20.7 & 27.2 & 27.9 & 27.5 & 28.1 & 29.5 \\
\hline
\end{tabular}

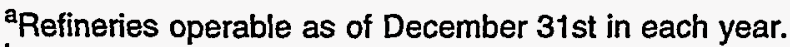

Included under Petroleos de Venezuela beginning in 1991.

'Closed as of October 2, 1992.

Included under Shell Oil Company prior to 1993. In 1993, Shell sold Pemex a 50-percent interest in its Deer Park, Texas, refinery.

${ }^{\text {A} A c q u i r e d ~ b y ~ C a s t l e ~ E n e r g y ~ i n ~} 1993$.

$\mathrm{NF}=$ No foreign affiliation during this period.

Sources: Energy Information Administration, Petroleum Supply Annual, DOE/EIA-0340 (Washington, DC), 1989-1993.

\section{Uranium Exploration and Development}

Even though the year 1993 was a decidedly poor one for U.S. uranium production companies, foreign- affiliated companies' expenditures on uranium exploration totaled $\$ 8.5$ million in 1993, a half-million dollar increase over 1992 (Table 12). Total U.S. expenditures fell to $\$ 11.3$ million in 1993 from $\$ 14.5$ million in 1992, while total employment in the uranium mining industry fell 44 percent. ${ }^{44}$ In 1993, foreign

\footnotetext{
${ }^{44}$ Energy Information Administration, Uranium Industry Annual 1993, DOE/EIA-0478(93) (Washington, DC, September 1994$)$, Table ES1.
} 
Table 10. Branded Retail Outlets and Total Gasoline Supplied by Foreign-Affiliated U.S. Companies, 1989-1993

\begin{tabular}{|c|c|c|c|c|c|}
\hline Company & 1989 & 1990 & 1991 & 1992 & 1993 \\
\hline & \multicolumn{5}{|c|}{ Total Branded Retail Outlets } \\
\hline Citgo Petroleum ${ }^{a}$ & 8,463 & 9,734 & 11,319 & 11,938 & 12,531 \\
\hline Star Enterprise $\ldots \ldots \ldots \ldots \ldots \ldots \ldots \ldots$ & 10,700 & 10,849 & 8,653 & 9,032 & 9,468 \\
\hline 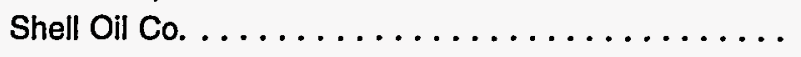 & 9,763 & 9,389 & 8,975 & 8,536 & 8,533 \\
\hline BP America $\ldots \ldots \ldots \ldots \ldots \ldots \ldots \ldots \ldots \ldots \ldots$ & 7,560 & 7,531 & 7,499 & 7,244 & 6,800 \\
\hline DuPont $\ldots \ldots \ldots \ldots \ldots \ldots \ldots \ldots \ldots \ldots \ldots$ & 4,915 & 4,659 & 4,612 & 4,829 & 4,947 \\
\hline Fina $\ldots \ldots \ldots \ldots \ldots \ldots \ldots \ldots \ldots \ldots \ldots \ldots \ldots \ldots \ldots \ldots$ & 3,177 & 3,136 & 2,919 & 2,539 & 2,704 \\
\hline Uno-Ven $\ldots \ldots \ldots \ldots \ldots \ldots \ldots \ldots \ldots \ldots$ & 3,550 & 2,950 & 3,257 & 3,004 & 2,651 \\
\hline Total Petroleum North America . . . . . . . . . . . . & 2,719 & 2,698 & 2,776 & 2,349 & 2,110 \\
\hline Clark Oil and Refining $\ldots \ldots \ldots \ldots \ldots \ldots$ & 944 & 937 & 887 & 873 & 845 \\
\hline 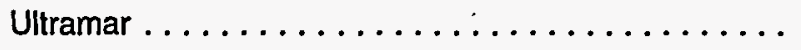 & 350 & 400 & 390 & NF & NF \\
\hline Tesoro Petroleum Corp. . .............. & 0 & 132 & 129 & 129 & 131 \\
\hline Hawailian Independent Refinery . . . . . . . . . . & 25 & 25 & 28 & 28 & 28 \\
\hline 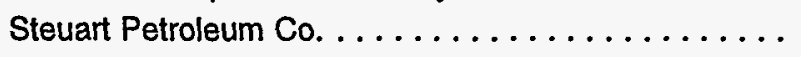 & 0 & 68 & 67 & 66 & 27 \\
\hline Total for Foreign-Affiliated Companies . . . . . . . . & 52,166 & 52,508 & 51,511 & 50,567 & 50,755 \\
\hline U.S. Total ${ }^{b} \ldots \ldots \ldots \ldots \ldots \ldots \ldots \ldots$ & 111,657 & 210,120 & 202,443 & 207,406 & 202,878 \\
\hline \multicolumn{6}{|l|}{ Foreign-Affiliated Companies as } \\
\hline \multirow[t]{2}{*}{ Percent of U.S. Total $\ldots \ldots \ldots \ldots \ldots \ldots \ldots$} & 46.7 & 25.0 & 25.4 & 24.4 & 25.0 \\
\hline & \multicolumn{5}{|c|}{$\begin{array}{l}\text { Total Gasoline Supplied } \\
\text { (thousand barrels per day) }\end{array}$} \\
\hline Total for Foreign-Affiliated Companies ${ }^{d}$ & 2,084 & 2,282 & 2,299 & 2,369 & 2,342 \\
\hline U.S. Total ${ }^{\theta} \ldots \ldots \ldots \ldots \ldots \ldots \ldots \ldots$ & 7,328 & 7,235 & 7,188 & 7,268 & 7,476 \\
\hline \multicolumn{6}{|l|}{ Foreign-Affiliated Companies as } \\
\hline Percent of U.S. Total . . . . . . . & 28.4 & 31.5 & 32.0 & 32.6 & 31.3 \\
\hline
\end{tabular}

a Jobber-supplied outlets.

${ }^{b}$ For 1989 , the total includes only service station establishments with 50 percent or more of their dollar volume from petroleum product sales. For 1990-1993, the total includes all establishments selling gasoline at retail.

'Gasoline Supplied refers to average daily gasoline shipments.

dDisaggregated company numbers are considered proprietary by the Energy Information Administration.

'Total gasoline supplied.

NF $=$ No foreign affiliation during this period.

Sources: Company station counts: National Petroleum News Factbook, 1990-1994 and annual reports to shareholders, except for DuPont (1990), for which data came from DuPont Data 1990, and Star Enterprise (1990), for which data came from National Petroleum News (October 1991). U.S. total outlets: 1989: National Petroleum News, 1990 Fact Book. 1990-1993: National Petroleum News, 1994 Fact Book (mid-June 1994). Company gasoline volumes: Energy Information Administration, Form EIA782c. Total gasoline supplied: Energy Information Administration, Monthly Energy Review, January 1995, DOE/EIA-0035(95/01) (Washington, DC, January 1995).

affiliates' spending on U.S. uranium exploration accounted for three-fourths of total U.S. spending. Foreign affiliates' investment in U.S. uranium mining is largely made up of subsidiaries of foreign electric utilities and mining companies. These investments were motivated by the need to find secure sources of uranium for overseas nuclear power plants. ${ }^{45}$ xv.

${ }^{45}$ Energy Information Administration, Uranium Industry Annual 1993, DOE/EIA-0478(93) (Washington, DC, September 1994), pp. xii and 
Table 11. Bituminous Coal and Lignite Production and Source of Ownership of Foreign-Affiliated Coal Companies in the United States, 1989-1993

\begin{tabular}{|c|c|c|c|c|c|}
\hline \multirow{2}{*}{$\begin{array}{l}\text { Controlling Companyl } \\
\text { Foreign-Ownership Interest }\end{array}$} & \multicolumn{5}{|c|}{$\begin{array}{l}\text { Coal Production } \\
\text { (thousand short tons) }\end{array}$} \\
\hline & 1989 & 1990 & 1991 & 1992 & 1993 \\
\hline $\begin{array}{l}\text { Peabody Holding Co. (Hanson plc) }{ }^{b} \ldots \ldots \ldots \\
\text { Consol Coal Group (DuPont) }\end{array}$ & 47,700 & 93,300 & 91,700 & 90,800 & 85,700 \\
\hline JES Holding, Inc., Rheinbraun AG & 53,500 & 54,600 & 55,200 & 56,300 & 45,600 \\
\hline $\begin{array}{l}\text { Shell Oil Co. } \\
\text { Royal Dutch/Shell ... }\end{array}$ & 25,500 & 24,600 & 24,300 & $\left({ }^{c}\right)$ & $\left(\mathcal{(}^{c}\right)$ \\
\hline $\begin{array}{l}\text { Kennecott Energy Co } \\
\text { RTZ plc ............. }\end{array}$ & 0 & 0 & 0 & 0 & 32,900 \\
\hline $\begin{array}{l}\text { Costain Coal Co. } \\
\text { Costain Group ....... }\end{array}$ & NA & NA & NA & 12,200 & 14,800 \\
\hline $\begin{array}{l}\text { Zeigler Coal Holding Co. } \\
\text { Royal Dutch/Shell Group }\end{array}$ & NF & NF & NF & 41.000 & 35,800 \\
\hline $\begin{array}{l}\text { Ashland Coal Co. } \\
\text { Saarbergwerke AG/Carborex ... }\end{array}$ & 7,000 & 10,700 & 12,200 & 16,700 & 14,200 \\
\hline Utah Minerals International, Inc. & & & & & \\
\hline Broken Hill Proprietary Co. ... & 15,200 & 15,300 & 11,200 & 13,400 & 13,200 \\
\hline $\begin{array}{l}\text { Westmoreland Coal Co. } \\
\text { Veba Kohle International }\end{array}$ & 10,800 & 11,700 & 11,600 & 11,800 & 11,600 \\
\hline $\begin{array}{l}\text { Andelex Resources, Inc. } \\
\text { Andelex Resources, Inc. }\end{array}$ & 3,900 & 4,000 & 4,400 & 5,400 & 4,300 \\
\hline Santa Fe Pacific Coal Corp. & & & & $0,+60$ & \\
\hline $\begin{array}{l}\text { Olympia and York, Ltd. } \ldots \ldots \ldots \\
\text { Pickands Mather \& Co. . . . . . }\end{array}$ & 2,342 & 2,743 & 4,200 & 3,400 & NA \\
\hline Steel Company of Canada .... & 3,130 & 3,130 & 3,300 & NA & NA \\
\hline $\begin{array}{l}\text { Great Western Coal, Inc. } \\
\text { Great Western Resources, Inc. }\end{array}$ & 3,374 & 2,969 & 3,000 & (d) & (d) \\
\hline New Horizons Coal Division & & & & & \\
\hline $\begin{array}{l}\text { Great Western Resources, Inc. . . . . . . . } \\
\text { Inspiration Coal, Inc. }\end{array}$ & NA & NA & NA & 2,256 & 4,575 \\
\hline Hudson Bay Mining \& Smelting Co. & 1,993 & 2,500 & 2,500 & 0 & 0 \\
\hline $\begin{array}{l}\text { Gulf Resources and Chemical } \\
\mathrm{HCl} \text { Holdings, Ltd./Private Investor }\end{array}$ & 1,709 & 2,192 & 1,800 & () & (') \\
\hline $\begin{array}{l}\text { Agip Coal, Inc. } \\
\text { Ente Nazionale Idrocarburi }\end{array}$ & 3,119 & 3,101 & 3,700 & 3,700 & 1,391 \\
\hline $\begin{array}{l}\text { NYCAL Corp. } \\
\text { C\&K Coal } \ldots \ldots \ldots \ldots\end{array}$ & NA & NA & NA & 1,324 & 1,055 \\
\hline $\begin{array}{l}\text { Carter-Roag Coal Co. } \\
\text { Marquard and Bahls Coal Co. }\end{array}$ & 540 & 604 & 754 & 577 & 513 \\
\hline $\begin{array}{l}\text { Marquard and Bahls Coal Co. } \ldots \\
\text { Cannelton Industries, Inc. }{ }^{9}\end{array}$ & & & & & \\
\hline $\begin{array}{l}\text { Algoma Steel, Ltd. . . . . . } \ldots \ldots \ldots \ldots \ldots \ldots \\
\text { Pyro Mining Co. }\end{array}$ & 4,536 & 5,393 & NF & NF & NF \\
\hline $\begin{array}{l}\text { Costain Group } \ldots \ldots \ldots \ldots \text {. . . } \\
\text { Old Ben Coal Co. (BP America) }\end{array}$ & 5,885 & 7,800 & 7,900 & $(n)$ & (") \\
\hline $\begin{array}{l}\text { British Petroleum .......... } \\
\text { M.A. Hanna Co. }\end{array}$ & 12,200 & 5,000 & 0 & 0 & 0 \\
\hline Brascan Ltd. . . . . . . . . & 4,200 & 4,085 & 0 & 0 & 0 \\
\hline $\begin{array}{l}\text { Total American Mining } \\
\text { Total Compagnie Francaise de Petroles ... }\end{array}$ & 42 & 0 & 0 & 0 & 0 \\
\hline
\end{tabular}


Table 11. Bituminous Coal and Lignite Production and Source of Ownership of Foreign-Affiliated Coal Companies in the United States, 1989-1993 (Continued)

\begin{tabular}{|c|c|c|c|c|c|}
\hline \multirow{2}{*}{$\begin{array}{l}\text { Controlling Company/ } \\
\text { Foreign-Ownership Interest }\end{array}$} & \multicolumn{5}{|c|}{$\begin{array}{l}\text { Coal Production } \\
\text { (thousand short tons) }\end{array}$} \\
\hline & 1989 & 1990 & 1991 & 1992 & 1993 \\
\hline \multicolumn{6}{|l|}{ Avery Coal Co. } \\
\hline Trafalgar Industries $\ldots \ldots \ldots \ldots$ & 283 & 0 & 0 & 0 & 0 \\
\hline \multicolumn{6}{|l|}{ Coal Corp of American (Shaker Div.) } \\
\hline Campbell Resources ......... & 60 & 0 & 0 & 0 & 0 \\
\hline Total Foreign-Affiliated ... & 207,013 & 253,717 & 237,754 & 258,857 & 265,634 \\
\hline Total United States $\ldots \ldots \ldots \ldots \ldots \ldots \ldots$ & 977,381 & $1,025,570$ & 992,539 & 994,062 & 941,118 \\
\hline Percent Foreign-Affiliated ...... & 21.2 & 24.7 & 24.0 & 26.0 & 28.2 \\
\hline
\end{tabular}

${ }^{a}$ Coal production refers to bituminous cual, subbituminous coal, and lignite coal production only.

bIn 1990, Hanson plc, a U.K. company, gained 100-percent ownership of Peabody Holding Company. For 1989, only Newmont Mining's ownership share of Peabody's production is shown, which was 54.97 percent.

'Sold coal assets to Zeigler Coal in 1992.

Included under New Horizons Coal Division.

๑1990 production from Inspiration Resources Corporation, 1990 Annual Report, p. 10. Acquired by Ross Harris in 1991.

'Acquired by NYCAL Corp. in 1991.

${ }^{9}$ Acquired by AMAX in 1991.

hIncluded under Costain Coal Co.

The estimate of 1990 production was derived as follows: Mingo Logan (2,200 thousand tons of production according to Ashland Coal) was sold in January and remaining coal operations were sold in July. So, estimated production $=(12,200-2,200) / 2=5,000$ thousand tons.

NA=Not available.

$N F=$ No foreign affiliation during this period.

Sources: Coal ownership: U.S. Securities and Exchange Commission Form 13-D; Moody's Industrial Manual, 1987-91; U.S. Department of Commerce, International Trade Administration, Foreign Direct Investment Activity in the United States. Coal company production data: 1993: 1994 Coal Mine Directory (Chicago, IL: Maclean Hunter Publishing Co., January 1994). 1992: 1994 Coal Mine Directory (Chicago, IL: Maclean Hunter Publishing Co., January 1994). 1991: 1993 Coal Mine Directory (Chicago, IL: Maclean Hunter Publishing Co., January 1993). 1990: 1992 Coal Mine Directory (Chicago, IL: Maclean Hunter Publishing Co., October 1991). U.S. total for coal production: Energy Information Administration, Coal Industry Annual 1993, DOE/EIA-0584(93) (Washington, DC, December 1994).

\section{Financial Performance of Foreign- Affiliated Companies}

The financial performance of foreign-affiliated energy companies in 1993 reflected a mixture of energy market developments. Positive contributions to bottom-line results came from a sharp upswing in natural gas prices, up 17 percent between 1992 and 1993, and a 3percent increase in U.S. demand for gasoline and distillate products. ${ }^{46}$ Declining crude oil prices, down about $\$ 2$ per barrel on an annual basis, hurt the income and cash flow of upstream producers. However, buoyant demand for gasoline and distillate restrained the fall in refined product prices which benefitted refiners' profits. ${ }^{47}$ Generally, natural gas-oriented producers and petroleum refiners experienced improved financial results while oil-oriented producers did not fare as well between 1992 and 1993.

With 28 percent of U.S. coal production traceable to foreign affiliates, developments in U.S. coal markets are also important to the financial performance of foreignaffiliated energy producers. A strike by the United Mine Workers of America against selected companies accounted for most of the 53-million ton drop in U.S.

\footnotetext{
${ }^{46}$ Energy Information Administration, Monthly Energy Review January 1995, DOE/EIA-0035(95/01)(Washington DC, January 1995), pp. 57, 59, and 125.

${ }^{17}$ Energy Information Administration, Annual Energy Review 1993, DOE/EIA-0384(93) (Washington, DC, July 1994), Tables 3.4 and 3.5.
} 
Figure 5. Production and Share of U.S. Total Bituminous Coal and Lignite for Foreign-Affiliated U.S. Companies, 1980-1993

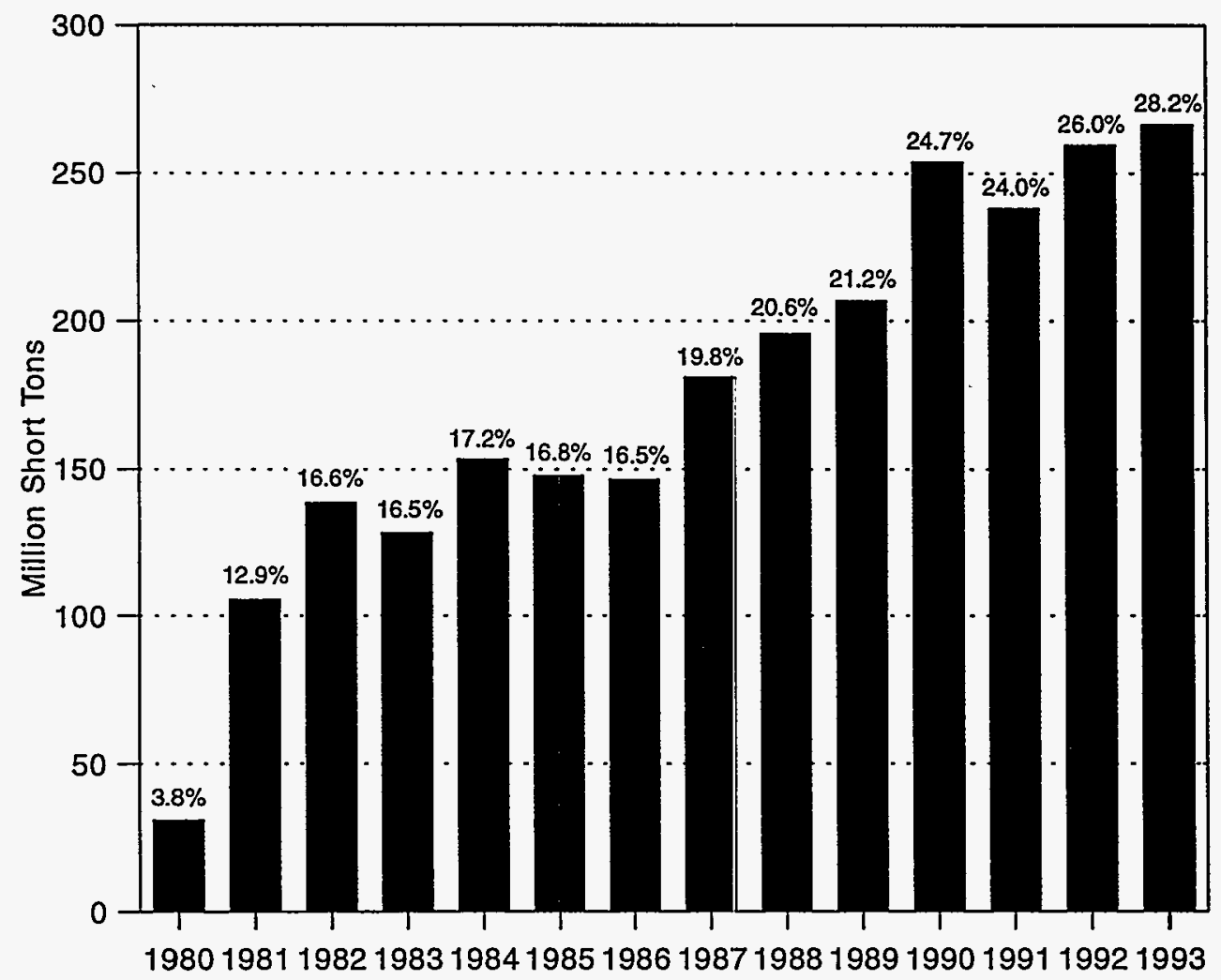

Note: Percentage values appearing above bars indicate foreign-affiliates' share of U.S. production.

Sources: 1981: Energy Information Administration, Profiles of Foreign Direct Investment in U.S. Energy 1983, DOE/EIA-0466 (Washington, DC, February 1985). 1982-1989: Keystone Coal Industry Manual, 1983-1990 Editions. 1990: 1992 Coal Mine Directory, (Chicago, IL: Maclean Hunter Publishing Co., October 1991). 1991: 1993 Coal Mine Directory (Chicago, IL: Maclean Hunter Publishing Co., January 1993). 1992: 1994 Coal Mine Directory (Chicago, IL: Maclean Hunter Publishing Co., January 1994). 1993: 1995 Coal Mine Directory (Chicago, IL: Maclean Hunter Publishing Co., January 1995). U.S. Totals: Energy Information Administration, Coal Industry Annual 1993, DOE/EIA-0584(93) (Washington, DC, December 1994).

coal production during 1993. Four of the five companies that bore the brunt of the selective strike were foreign affiliates: Peabody Holding Company, Consolidation Coal Company, Zeigler Coal Holding Company, and Ashland Coal. ${ }^{8}$ Although coal consumption rose 4 percent, average prices at the mine were down 6 percent between 1992 and 1993. The strike and lower coal prices had adverse effects on bottom-line results of foreign-affiliated coal producers. Three of the strike- affected affiliates (Ashland Coal, Peabody's parent Hanson's coal segment, and Zeigler Coal Holding) in total reported a 66-percent decline in net income (excluding extraordinary items) between 1992 and $1993 .{ }^{49}$

On balance, the net income of foreign-affiliated U.S. energy companies, excluding the cumulative effects of accounting changes, ${ }^{50}$ at $\$ 2.2$ billion in 1993 was only 5 percent above the 1992 level (Table 13). For other

\footnotetext{
${ }^{48}$ Energy Information Administration, Coal Industry Annual 1993, DOE/EIA-0584(93) (Washington, DC, December 1994), p. xi.

${ }^{49}$ The impact on Consol could not be assessed. DuPont reports the financial results for its 50-percent owned Consol joint venture as an unconsolidated subsidiary. For all of its unconsolidated subsidiaries, which include Consol and DuPont Merck Pharmaceutical Company, DuPont reported net income of \$216 million in 1992 and \$121 million in 1993.

${ }^{50}$ Net income disclosed by foreign affiliates as well as by other U.S. energy companies was strongly affected by the adoption of Financial Accounting Standard No. 106, "Employers Accounting for Postretirement Benefits Other than Pensions" (SFAS 106). This standard required most U.S. corporations to recognize the cumulative effect of current and future obligations as a charge against income in 1992. However, the purpose of the charge was to establish a liability on the balance sheet, which neither involved cash nor was related to financial results from ongoing operations.
} 
Table 12. Foreign Participation in U.S. Uranium Exploration and Development, 1976-1993

\begin{tabular}{|c|c|c|c|c|c|}
\hline & & $\begin{array}{c}\text { Exploration and } \\
\text { Development } \\
\text { Expenditures by } \\
\text { Foreign Companies }\end{array}$ & $\begin{array}{l}\text { Total U.S. } \\
\text { Exploration and } \\
\text { Development } \\
\text { Expenditures }\end{array}$ & $\begin{array}{c}\text { Foreign } \\
\text { Expenditures } \\
\text { as a Percent } \\
\text { of U.S. Total }\end{array}$ & $\begin{array}{l}\text { Number of Foreign- } \\
\text { Affiliated Companies }\end{array}$ \\
\hline & & \multicolumn{2}{|c|}{ (million dollars) } & & \\
\hline 1976 & 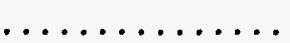 & 13.2 & 170.7 & 8 & 15 \\
\hline 1977 & $\ldots \ldots \ldots \ldots \ldots$ & 21.7 & 258.1 & 8 & 17 \\
\hline 1978 & $\ldots \ldots \ldots \ldots$ & 39.3 & 314.3 & 13 & 31 \\
\hline 1979 & $\ldots \ldots \ldots \ldots \ldots$ & 34.1 & 315.9 & 11 & 28 \\
\hline 1980 & 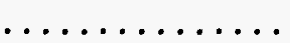 & 37.6 & 267.0 & 14 & 28 \\
\hline 1981 & $\ldots \ldots \ldots \ldots \ldots$ & 24.6 & 144.8 & 17 & 25 \\
\hline 1982 & $\ldots \ldots \ldots \ldots \ldots$ & 14.6 & 73.6 & 20 & 14 \\
\hline 1983 & $\ldots \ldots \ldots \ldots \ldots$ & 4.8 & 36.9 & 13 & 9 \\
\hline 1984 & $\ldots \ldots \ldots \ldots \ldots$ & 6.6 & 26.5 & 25 & 9 \\
\hline 1985 & $\ldots \ldots \ldots \ldots \ldots$ & 5.6 & 20.1 & 28 & 6 \\
\hline 1986 & $\ldots \ldots \ldots \ldots \ldots$ & 12.0 & 22.1 & 54 & 8 \\
\hline 1987 & 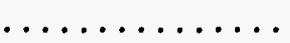 & 11.9 & 19.7 & 60 & 11 \\
\hline 1988 & $\ldots \ldots \ldots \ldots \ldots$ & 8.9 & 20.1 & 44 & 11 \\
\hline 1989 & $\ldots \ldots \ldots \ldots \ldots$ & 6.1 & 14.8 & 41 & 7 \\
\hline 1990 & $\ldots \ldots \ldots \ldots \ldots$ & 2.5 & 17.1 & 15 & 9 \\
\hline 1991 & $\ldots \ldots \ldots \ldots \ldots$ & 3.5 & 17.8 & 19 & 6 \\
\hline 1992 & $\ldots \ldots \ldots \ldots \ldots$ & 8.0 & 14.5 & 55 & 6 \\
\hline 1993 & $\ldots \ldots \ldots \ldots \ldots$ & 8.5 & 11.3 & 76 & 7 \\
\hline
\end{tabular}

Source: Energy Information Administration, Uranium Industry Annual 1993, DOE/EIA-0478(93) (Washington, DC, September 1994), pp.8-9.

energy companies, the comparable increase was a considerably greater 27 percent. The difference in financial results in part reflected the effects the 1993 strike activity had on foreign-affiliated coal producers and foreign affiliates' greater commitment to oil production. In 1993, the foreign-affiliated share of U.S. oil production, at 15 percent, was nearly double their share of U.S. natural gas production. Both groups of energy companies showed improved profitability, as measured by return on equity, from 1992 to 1993 as did U.S. manufacturing in general (Figure 6).
Although the foreign affiliates registered less improvement in income than did other U.S. energy companies, their revenues were up 5 percent compared with a 3percent drop in revenues for other U.S. energy companies. The apparent growth between 1992 and 1993 was largely traceable to the addition of Lyondell Petrochemical Company to the ranks of the foreign affiliates. Excluding Lyondell, with its revenue of $\$ 3.9$ billion, and the five other companies that became foreign affiliates in 1993, revenue of foreign-affiliated U.S. energy companies declined 1 percent between 1992 and 1993. 
Table 13. Selected Financial Information for Foreign-Affiliated U.S. Energy Companies, 1992-1993

\begin{tabular}{|c|c|c|c|c|c|c|}
\hline \multirow[b]{2}{*}{ Category } & \multicolumn{3}{|c|}{$\begin{array}{l}\text { Foreign-Affiliated U.S. Energy } \\
\text { Companies }^{a}\end{array}$} & \multicolumn{3}{|c|}{$\begin{array}{l}\text { U.S. Energy Industry } \\
\text { Comparison Group }\end{array}$} \\
\hline & 1992 & 1993 & $\begin{array}{l}\text { Percent } \\
\text { Change }\end{array}$ & 1992 & 1993 & $\begin{array}{l}\text { Percent } \\
\text { Change }\end{array}$ \\
\hline & \multicolumn{2}{|c|}{ (billion dollars) } & & \multicolumn{2}{|c|}{ (billion dollars) } & \\
\hline \multicolumn{7}{|l|}{ Financial Items } \\
\hline Net Income $\quad \ldots \ldots \ldots \ldots \ldots \ldots \ldots$ & -3.5 & 1.9 & NM & 6.2 & 14.3 & 130.6 \\
\hline Excluding Effects of Accounting Changes . & 2.1 & 2.2 & 4.6 & 11.3 & 14.4 & 27.3 \\
\hline Cash Flow $^{c} \ldots \ldots \ldots \ldots \ldots \ldots$ & 8.8 & 12:2 & 38.9 & 38.6 & 44.0 & 13.9 \\
\hline Capital Outlays $\ldots \ldots \ldots \ldots \ldots \ldots$ & 10.7 & 9.3 & -12.9 & 38.6 & 40.3 & 4.2 \\
\hline Cash Dividends $\ldots \ldots \ldots \ldots \ldots \ldots \ldots$ & 2.5 & 2.6 & 5.5 & 11.6 & 12.8 & 10.4 \\
\hline Return on Equity ${ }^{d}$ & -9.2 & 5.0 & & 4.3 & 9.4 & \\
\hline Dividends/Net Income $\ldots \ldots \ldots \ldots \ldots$ & NM & 133.8 & & 188.1 & 90.0 & \\
\hline Dividends/Cash Flow . . . . . . . . . . & 28.1 & 21.3 & & 30.2 & 29.2 & \\
\hline Debt/Equity $^{e} \ldots \ldots \ldots \ldots \ldots \ldots$ & 45.2 & 45.2 & & 58.3 & 55.0 & \\
\hline
\end{tabular}

ancludes incorporated U.S. energy companies that are foreign affiliated and for which publicly reported financial information is available. Also included are foreign parent companies for which data for U.S. operations were not separately disclosed. For 1992, these companies were: Anadarko Petroleum Corp., Arabian Shield Development Co., Ashland Coal Inc., Avalon Corp., Bellwether Exploration Co., Blue Dolphin Energy Co., Cairn Energy USA Inc., Caspen Oil Inc., Castle Energy Corp., Chieftain International Inc., Citgo Petroleum, DI Industries, Inc., Daleco Resources Corp., E.I. du Pont de Nemours and Company, Exploration Company, Fina Inc., Georesources Inc., Gold King Consolidated Inc., Gulf USA Corp., Harcor Energy Co., Harken Energy Corp., Hondo Oil and Gas Co., Horsham Corp., MSR Exploration, Magellan Petroleum Corp., Norcen Energy Resources Lid., Oceanic Exploration Co., Penn Virginia Corp., Pogo Producing Co., Presidio Oil Co., Ranger Oil Ltd., Reading \& Bates Corp., Rio Algom Ltd., Saba Petroleum Co., Santa Fe Energy Resources Inc., Schlumberger Ltd., Shell Oil Co., Sunlite Inc., Taurus Petroleum Inc., Tesoro Petroleum Corp., Total Petroleum (North America), Westmoreland Coal Co., XCL Ltd., and Zeigler Coal Holding Co. In 1993, the following U.S. energy companies became foreign affiliated or, if foreign based, acquired U.S. energy reserves or refining capacity: Arakis Energy Corp., Canadian Occidental Petroleum Ltd., Com-Tek Resources Inc., Louis Dreyfus Natural Gas Corp., Lyondell Petrochemical Co., and Zapata Corp. The following companies were not included in 1993: New London Inc. and Pogo Producing Co.

'The comparison group is derived from aggregates available from Standard and Poor's Compustat II Industrial File for the following four digit (SIC) industries: 1220 (bituminous coal, lignite mining), 1221 (bituminous coal, lignite surface mining), 1311 (crude petroleum and natural gas production), 1381 (oil and gas well drilling), 1382 (oil and gas field exploration), 1389 (oil and gas field services not elsewhere classified), and 2911 (petroleum refining). The Compustat aggregates are adjusted by subtracting out data for companies which have been identified as foreign affiliated, or whose operations are foreign based, or foreign-based companies whose U.S. operations are already included in U.S. companies identified as foreign affiliated.

Measured as cash flow from operations.

'Defined as net income divided by year-end stockholders' equity.

'Defined as year-end long-term debt divided by year-end stockholders' equity.

NM=Not meaningful.

Note: Percent changes were calculated from unrounded data.

Source: Compiled from Compustat II Industrial File and company annual reports. 
Figure 6. Return on Stockholders' Equity for Foreign-Affiliated U.S. Energy Companies, Other U.S. Energy Companies, and All U.S. Manufacturing Corporations, 1980-1993

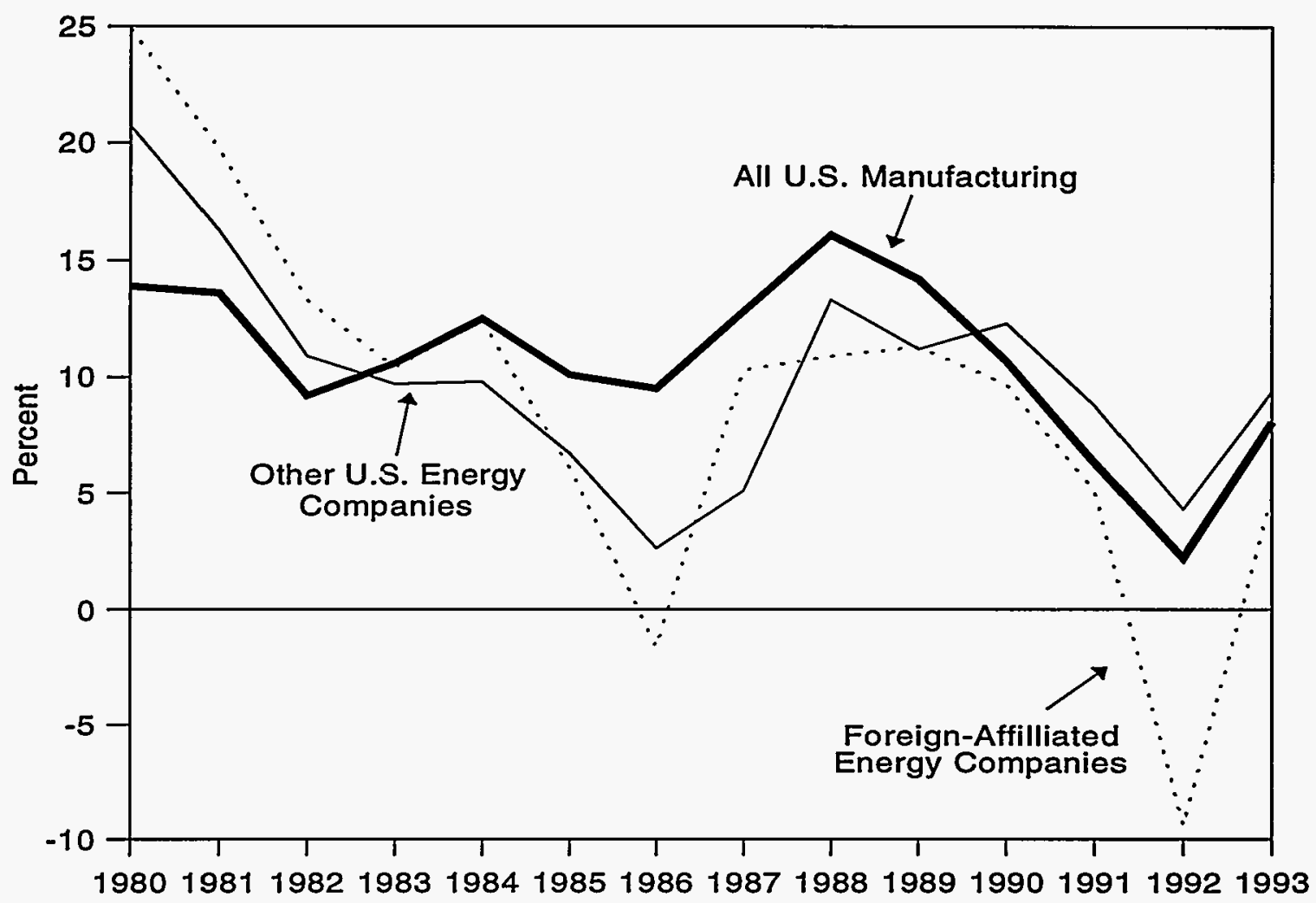

Note: A substantial portion of the 1992 decline is attributable to the adoption of Financial Accounting Standard (FAS) 106 discussed in Chapter 4. Excluding the effects of accounting changes, mainly FAS 106, retum on equity for foreign-affiliated energy companies in 1992 was 4.5 percent, 7.7 percent for other U.S. energy companies, and 8.3 percent for all U.S. manufacturing.

Sources: Energy companies: Compustat II Industrial File and company annual reports. All U.S. manufacturing corporations: Economic Report of the President, February 1995. 

Appendix

\section{Completed Foreign \\ Direct Investment \\ Transactions, 1993}


Table A1. Completed Transactions by Size in the Petroleum Industry from January 1993 Through December 1993-Acquisitions and Divestitures

\begin{tabular}{|c|c|c|c|c|c|c|}
\hline $\begin{array}{l}\text { Acquiring } \\
\text { Company }\end{array}$ & $\begin{array}{c}\text { Acquiring } \\
\text { Company Activity }\end{array}$ & $\begin{array}{l}\text { Affected } \\
\text { Company }\end{array}$ & $\begin{array}{c}\text { Affected } \\
\text { Company Activity }\end{array}$ & $\begin{array}{c}\text { Type of } \\
\text { Transaction }\end{array}$ & $\begin{array}{c}\text { Size of } \\
\text { Transaction } \\
\text { (million dollars) }\end{array}$ & $\begin{array}{c}\text { Date of } \\
\text { Transaction }\end{array}$ \\
\hline & & & Acquisitions & & & \\
\hline $\begin{array}{l}\text { Schlumberger } \\
\text { Ltd. } \\
\text { (Netherlands) }\end{array}$ & $\begin{array}{l}\text { Oil and gas } \\
\text { exploration } \\
\text { services }\end{array}$ & $\begin{array}{l}\text { Dowell } \\
\text { Schlumberger, Inc. }\end{array}$ & $\begin{array}{l}\text { Oil and gas well- } \\
\text { drilling services }\end{array}$ & $\begin{array}{l}\text { Equity } \\
\text { acquisition }\end{array}$ & 675.0 & January \\
\hline $\begin{array}{l}\text { Metallgesellschaft } \\
\text { (Germany) } \\
\text { Castle Energy } \\
\text { Corp. }\end{array}$ & $\begin{array}{l}\text { Petroleum refining, } \\
\text { oil and gas } \\
\text { exploration and } \\
\text { production }\end{array}$ & Powerine Oil Co. & Petroleum refining & Merger & 145.0 & October \\
\hline $\begin{array}{l}\text { Louis Dreyfus } \\
\text { et CIE } \\
\text { (France) } \\
\text { Louis Dreytus } \\
\text { Natural Gas Corp. }\end{array}$ & $\begin{array}{l}\text { Oil and gas } \\
\text { exploration and } \\
\text { production }\end{array}$ & $\begin{array}{l}\text { Parker and Parsely } \\
\text { Petroleum Co. }\end{array}$ & $\begin{array}{l}\text { Oil and gas } \\
\text { exploration and } \\
\text { production }\end{array}$ & $\begin{array}{l}\text { Property } \\
\text { acquisition }\end{array}$ & 138.0 & November \\
\hline $\begin{array}{l}\text { Petroleos de } \\
\text { Venezuela S.A. } \\
\text { (Venezuela) } \\
\text { Citgo Petroleum } \\
\text { Co. }\end{array}$ & $\begin{array}{l}\text { Petroleum refining } \\
\text { and marketing, } \\
\text { petroleum products }\end{array}$ & $\begin{array}{l}\text { Lyondell } \\
\text { Petrochemical Co. }\end{array}$ & Petroleum refining & Joint venture & 119.0 & July \\
\hline $\begin{array}{l}\text { Norcen Energy } \\
\text { Resources Ltd. } \\
\text { (Canada) }\end{array}$ & $\begin{array}{l}\text { Oil and gas } \\
\text { exploration and } \\
\text { production }\end{array}$ & $\begin{array}{l}\text { Torch Energy } \\
\text { Advisors Inc. }\end{array}$ & $\begin{array}{l}\text { Oil and gas } \\
\text { exploration and } \\
\text { production }\end{array}$ & $\begin{array}{l}\text { Property } \\
\text { acquisition }\end{array}$ & 105.8 & December \\
\hline $\begin{array}{l}\text { Norex America } \\
\text { (Cayman Islands) } \\
\text { Zapata Corp. }\end{array}$ & $\begin{array}{l}\text { Natural gas } \\
\text { transmission }\end{array}$ & $\begin{array}{l}\text { Energy Industries } \\
\text { Inc. }\end{array}$ & $\begin{array}{l}\text { Natural gas } \\
\text { compression } \\
\text { equipment }\end{array}$ & $\begin{array}{l}\text { Equity } \\
\text { acquisition }\end{array}$ & 87.5 & June \\
\hline $\begin{array}{l}\text { Forcenergy } \\
\text { (Sweden) }\end{array}$ & $\begin{array}{l}\text { Oil and gas } \\
\text { exploration and } \\
\text { production }\end{array}$ & Unidentified & NA & $\begin{array}{l}\text { Property } \\
\text { acquisition }\end{array}$ & 32.5 & May \\
\hline $\begin{array}{l}\text { Forcenergy } \\
\text { (Sweden) }\end{array}$ & $\begin{array}{l}\text { Oil and gas } \\
\text { exploration and } \\
\text { production }\end{array}$ & Unidentified & NA & $\begin{array}{l}\text { Property } \\
\text { acquisition }\end{array}$ & 30.0 & November \\
\hline $\begin{array}{l}\text { Norex America } \\
\text { Inc. } \\
\text { (Cayman Islands) }\end{array}$ & $\begin{array}{l}\text { Oil and gas field } \\
\text { services }\end{array}$ & Zapata Corp. & $\begin{array}{l}\text { Natural gas } \\
\text { transmission }\end{array}$ & $\begin{array}{l}\text { Equity } \\
\text { acquisition }\end{array}$ & 28.8 & May \\
\hline $\begin{array}{l}\text { Sonatrach } \\
\text { Petroleum } \\
\text { Investment Corp. } \\
\text { (Algeria) } \\
\text { Anadarko } \\
\text { Petroleum Corp. }\end{array}$ & $\begin{array}{l}\text { Oil and gas } \\
\text { exploration and } \\
\text { production }\end{array}$ & Unidentified & NA & $\begin{array}{l}\text { Property } \\
\text { acquisition }\end{array}$ & 20.0 & June \\
\hline $\begin{array}{l}\text { Abdullah Taha } \\
\text { Bakhsh } \\
\text { (Saudi Arabia) } \\
\text { Harken Energy } \\
\text { Corp. }\end{array}$ & $\begin{array}{l}\text { Drilling oil and gas } \\
\text { wells }\end{array}$ & $\begin{array}{l}\text { Chuska Resources } \\
\text { Corp }\end{array}$ & $\begin{array}{l}\text { Oil and gas } \\
\text { exploration and } \\
\text { production }\end{array}$ & $\begin{array}{l}\text { Equity } \\
\text { acquisition }\end{array}$ & 17.8 & February \\
\hline
\end{tabular}


Table A1. Completed Transactions by Size in the Petroleum Industry from January 1993 Through December 1993-Acquisitions ancl Divestitures (Continued)

\begin{tabular}{|c|c|c|c|c|c|c|}
\hline $\begin{array}{l}\text { Acquiring } \\
\text { Company }\end{array}$ & $\begin{array}{c}\text { Acquiring } \\
\text { Company Activity }\end{array}$ & $\begin{array}{l}\text { Affected } \\
\text { Company }\end{array}$ & $\begin{array}{c}\text { Affected } \\
\text { Company Activity }\end{array}$ & $\begin{array}{c}\text { Type of } \\
\text { Transaction }\end{array}$ & $\begin{array}{c}\text { Size of } \\
\text { Transaction } \\
\text { (million dollars) }\end{array}$ & $\begin{array}{c}\text { Date of } \\
\text { Transaction }\end{array}$ \\
\hline & & \multicolumn{3}{|c|}{ Acquisitions (Continued) } & & \\
\hline $\begin{array}{l}\text { Norex America } \\
\text { (United Kingdom) } \\
\text { Cimarron Gas Co. }\end{array}$ & $\begin{array}{l}\text { Natural gas } \\
\text { transmission }\end{array}$ & Stellar Cos. & $\begin{array}{l}\text { Natural gas } \\
\text { gathering and } \\
\text { processing }\end{array}$ & $\begin{array}{l}\text { Equity } \\
\text { acquisition }\end{array}$ & 16.0 & September \\
\hline $\begin{array}{l}\text { Barntex Inc. } \\
\text { (United Kingdom) } \\
\text { Bellwether } \\
\text { Exploration Co. }\end{array}$ & $\begin{array}{l}\text { Oil and gas } \\
\text { exploration and } \\
\text { production }\end{array}$ & Snyder Oil Co. & $\begin{array}{l}\text { Natural gas } \\
\text { processing }\end{array}$ & $\begin{array}{l}\text { Equity } \\
\text { acquisition }\end{array}$ & 9.2 & July \\
\hline $\begin{array}{l}\text { Coho Resources } \\
\text { Ltd. } \\
\text { (Canada) } \\
\text { Coho Resources } \\
\text { Inc. }\end{array}$ & $\begin{array}{l}\text { Oil and gas } \\
\text { exploration and } \\
\text { production }\end{array}$ & Unidentified & NA & $\begin{array}{l}\text { Property } \\
\text { acquisition }\end{array}$ & 7.6 & November \\
\hline $\begin{array}{l}\text { Channel Hotels \& } \\
\text { Properties Ltd. } \\
\text { (United Kingdom) }\end{array}$ & NA & Nycal Corp. & $\begin{array}{l}\text { Insurance services, } \\
\text { oil and gas } \\
\text { exploration and } \\
\text { production }\end{array}$ & $\begin{array}{l}\text { Equity } \\
\text { acquisition }\end{array}$ & 7.0 & First quarter \\
\hline $\begin{array}{l}\text { Pittencrief plc } \\
\text { (United Kingdom) }\end{array}$ & NA & Exxon Corp. & $\begin{array}{l}\text { Oil and gas } \\
\text { exploration and } \\
\text { production }\end{array}$ & $\begin{array}{l}\text { Property } \\
\text { acquisition }\end{array}$ & 3.8 & March \\
\hline $\begin{array}{l}\text { Forcenergy } \\
\text { (Sweden) }\end{array}$ & NA & Unidentified & NA & $\begin{array}{l}\text { Property } \\
\text { acquisition }\end{array}$ & 3.5 & $\begin{array}{l}\text { Fourth } \\
\text { quarter }\end{array}$ \\
\hline $\begin{array}{l}\text { AGF Management } \\
\text { Ltd. } \\
\text { (Canada) } \\
\text { HarCor Energy Inc. }\end{array}$ & $\begin{array}{l}\text { Oil and gas } \\
\text { exploration and } \\
\text { production }\end{array}$ & Unidentified & NA & $\begin{array}{l}\text { Property } \\
\text { acquisition }\end{array}$ & 3.0 & July \\
\hline $\begin{array}{l}\text { Abdullah Taha } \\
\text { Bakhsh } \\
\text { (Saudi Arabia) } \\
\text { Harken Energy } \\
\text { Corp. }\end{array}$ & $\begin{array}{l}\text { Drilling oil and gas } \\
\text { wells }\end{array}$ & Unidentified & NA & $\begin{array}{l}\text { Property } \\
\text { acquisition }\end{array}$ & 1.6 & March \\
\hline $\begin{array}{l}\text { AGF Management } \\
\text { Ltd. } \\
\text { (Canada) } \\
\text { HarCor Energy Inc. }\end{array}$ & $\begin{array}{l}\text { Oil and gas } \\
\text { exploration and } \\
\text { production }\end{array}$ & $\begin{array}{l}\text { Unidentified } \\
\text { limited partnership }\end{array}$ & $\begin{array}{l}\text { Oil and gas } \\
\text { exploration and } \\
\text { production }\end{array}$ & $\begin{array}{l}\text { Property } \\
\text { acquisition }\end{array}$ & 1.1 & May \\
\hline $\begin{array}{l}\text { Aran plc } \\
\text { (United Kingdom) } \\
\text { Aran Energy Inc. }\end{array}$ & $\begin{array}{l}\text { Oil and gas } \\
\text { exploration and } \\
\text { production }\end{array}$ & Unidentified & NA & $\begin{array}{l}\text { Property } \\
\text { acquisition }\end{array}$ & 0.6 & April \\
\hline $\begin{array}{l}\text { British Petroleum } \\
\text { plc } \\
\text { (United Kingdom) } \\
\text { BP Exploration Co. }\end{array}$ & $\begin{array}{l}\text { Integrated } \\
\text { petroleum } \\
\text { operations }\end{array}$ & Chevron Corp. & $\begin{array}{l}\text { Oil and gas } \\
\text { exploration and } \\
\text { production }\end{array}$ & $\begin{array}{l}\text { Property } \\
\text { acquisition }\end{array}$ & NA & December \\
\hline
\end{tabular}

$\mathrm{NA}=$ Not available.

See notes at end of table. 
Table A1. Completed Transactions by Size in the Petroleum Industry from January 1993

Through December 1993-Acquisitions and Divestitures (Continued)

\begin{tabular}{|c|c|c|c|c|c|c|}
\hline $\begin{array}{l}\text { Acquiring } \\
\text { Company }\end{array}$ & $\begin{array}{c}\text { Acquiring } \\
\text { Company Activity }\end{array}$ & $\begin{array}{l}\text { Affected } \\
\text { Company }\end{array}$ & $\begin{array}{c}\text { Affected } \\
\text { Company Activity }\end{array}$ & $\begin{array}{l}\text { Type of } \\
\text { Transaction }\end{array}$ & $\begin{array}{c}\text { Size of } \\
\text { Transaction } \\
\text { (million dollars) }\end{array}$ & $\begin{array}{c}\text { Date of } \\
\text { Transaction }\end{array}$ \\
\hline & & \multicolumn{3}{|c|}{ Acquisitions (Continued) } & & \\
\hline $\begin{array}{l}\text { Royal } \\
\text { Dutch/Shell } \\
\text { Group } \\
\text { (U.K., } \\
\text { Netherlands) } \\
\text { Shell Oil Co. }\end{array}$ & $\begin{array}{l}\text { Integrated petroleum } \\
\text { operations }\end{array}$ & BP America & $\begin{array}{l}\text { Petroleum } \\
\text { marketing }\end{array}$ & $\begin{array}{l}\text { Asset } \\
\text { acquisition }\end{array}$ & NA & June \\
\hline $\begin{array}{l}\text { Royal } \\
\text { Dutch/Shell } \\
\text { Group } \\
\text { (U.K., } \\
\text { Netherlands) } \\
\text { Shell Oil Co. }\end{array}$ & $\begin{array}{l}\text { Integrated petroleum } \\
\text { operations }\end{array}$ & Ashland Oil Inc. & $\begin{array}{l}\text { Petroleum } \\
\text { Marketing }\end{array}$ & $\begin{array}{l}\text { Asset } \\
\text { acquisition }\end{array}$ & NA & April \\
\hline $\begin{array}{l}\text { Petroleos de } \\
\text { Venezuela } \\
\text { (Venezuela) } \\
\text { Citgo Petroleum } \\
\text { Corp. }\end{array}$ & $\begin{array}{l}\text { Petroleum refining, } \\
\text { marketing }\end{array}$ & Amoco Corp. & Petroleum refining & $\begin{array}{l}\text { Asset } \\
\text { acquisition }\end{array}$ & NA & May \\
\hline $\begin{array}{l}\text { Louisiana Land } \\
\text { \& Exploration } \\
\text { Co. }\end{array}$ & $\begin{array}{l}\text { Oil and gas } \\
\text { exploration and } \\
\text { production }\end{array}$ & $\begin{array}{l}\text { RTZ Corp. plc } \\
\text { (United Kingdom) } \\
\text { Nerco Inc. }\end{array}$ & $\begin{array}{l}\text { Oil and gas } \\
\text { exploration and } \\
\text { production, coal } \\
\text { mining }\end{array}$ & $\begin{array}{l}\text { Property } \\
\text { acquisition }\end{array}$ & 353.7 & September \\
\hline Tosco Corp. & $\begin{array}{l}\text { Petroleum refining, } \\
\text { chemicals }\end{array}$ & $\begin{array}{l}\text { British Petroleum } \\
\text { plc } \\
\text { (United Kingdom) } \\
\text { BP America. }\end{array}$ & Petroleum refining & $\begin{array}{l}\text { Asset } \\
\text { acquisition }\end{array}$ & 175.0 & December \\
\hline $\begin{array}{l}\text { Western Gas } \\
\text { Resources Inc. }\end{array}$ & $\begin{array}{l}\text { Gas transmission } \\
\text { and distribution }\end{array}$ & $\begin{array}{l}\text { RTZ Corp. plc } \\
\text { (United Kingdom) } \\
\text { Nerco, Inc. }\end{array}$ & $\begin{array}{l}\text { Oil and gas } \\
\text { exploration and } \\
\text { production, coal } \\
\text { mining }\end{array}$ & $\begin{array}{l}\text { Property } \\
\text { acquisition }\end{array}$ & 156.1 & September \\
\hline $\begin{array}{l}\text { Castle Energy } \\
\text { Corp. }\end{array}$ & Petroleum refining & $\begin{array}{l}\text { Sargent Holding } \\
\text { Co. } \\
\text { (Austria) } \\
\text { Powerine Oil Co. }\end{array}$ & Petroleum refining & Merger & 145.0 & July \\
\hline $\begin{array}{l}\text { Western Gas } \\
\text { Resources Inc. }\end{array}$ & $\begin{array}{l}\text { Gas transmission } \\
\text { and distribution }\end{array}$ & $\begin{array}{l}\text { RTZ Corp. plc } \\
\text { (United Kingdom) } \\
\text { Nerco, Inc. }\end{array}$ & $\begin{array}{l}\text { Oil and gas } \\
\text { exploration and } \\
\text { production, coal } \\
\text { mining }\end{array}$ & $\begin{array}{l}\text { Asset } \\
\text { acquisition }\end{array}$ & 128.0 & September \\
\hline
\end{tabular}

$N A=$ Not available.

See notes at end of table. 


\section{Table A1. Completed Transactions by Size in the Petroleum Industry from January 1993}

Through December 1993-Acquisitions and Divestitures (Continued)

\begin{tabular}{|c|c|c|c|c|c|c|}
\hline $\begin{array}{l}\text { Acquiring } \\
\text { Company }\end{array}$ & $\begin{array}{c}\text { Acquiring } \\
\text { Company Activity }\end{array}$ & $\begin{array}{l}\text { Affected } \\
\text { Company }\end{array}$ & $\begin{array}{l}\text { Affected } \\
\text { Company } \\
\text { Activity }\end{array}$ & $\begin{array}{c}\text { Type of } \\
\text { Transaction }\end{array}$ & $\begin{array}{l}\text { Size of } \\
\text { Transaction } \\
\text { (million dollars) }\end{array}$ & $\begin{array}{l}\text { Date of } \\
\text { Transaction }\end{array}$ \\
\hline & & \multicolumn{3}{|c|}{ Divestitures (Continued) } & & \\
\hline $\begin{array}{l}\text { General Atlantic } \\
\text { Resources Inc. }\end{array}$ & $\begin{array}{l}\text { Oil and gas } \\
\text { exploration and } \\
\text { production }\end{array}$ & $\begin{array}{l}\text { Broken Hills } \\
\text { Proprietary Co. Ltd. } \\
\text { (Australia) } \\
\text { BHP Petroleum Inc. }\end{array}$ & $\begin{array}{l}\text { Oil and gas } \\
\text { exploration and } \\
\text { production }\end{array}$ & $\begin{array}{l}\text { Property } \\
\text { acquisition }\end{array}$ & 69.2 & April \\
\hline Devon Energy Corp. & $\begin{array}{l}\text { Oil and gas } \\
\text { exploration and } \\
\text { production }\end{array}$ & $\begin{array}{l}\text { Petrofina S.A. } \\
\text { (Belgium) } \\
\text { Fina Inc. }\end{array}$ & $\begin{array}{l}\text { Oil and gas } \\
\text { exploration and } \\
\text { production }\end{array}$ & $\begin{array}{l}\text { Property } \\
\text { acquisition }\end{array}$ & 54.0 & June \\
\hline Hadson Corp. & $\begin{array}{l}\text { Natural gas } \\
\text { transmission, } \\
\text { distribution and } \\
\text { storage }\end{array}$ & $\begin{array}{l}\text { Andrew Sarlos } \\
\text { (Canada) } \\
\text { Santa Fe Energy } \\
\text { Resources Inc. }\end{array}$ & $\begin{array}{l}\text { Natural gas } \\
\text { gathering and } \\
\text { processing }\end{array}$ & $\begin{array}{l}\text { Asset } \\
\text { acquisition }\end{array}$ & 52.0 & December \\
\hline $\begin{array}{l}\text { Vintage Petroleum } \\
\text { Inc. }\end{array}$ & $\begin{array}{l}\text { Oil and gas } \\
\text { exploration }\end{array}$ & $\begin{array}{l}\text { Andrew Sarlos } \\
\text { (Canada) } \\
\text { Santa Fe Energy } \\
\text { Resources Inc. }\end{array}$ & $\begin{array}{l}\text { Oil and gas } \\
\text { exploration } \\
\text { and production }\end{array}$ & $\begin{array}{l}\text { Property } \\
\text { acquisition }\end{array}$ & 48.0 & November \\
\hline $\begin{array}{l}\text { Triumph Oil and } \\
\text { Gas Corp. }\end{array}$ & $\begin{array}{l}\text { Oil and gas } \\
\text { exploration and } \\
\text { production }\end{array}$ & $\begin{array}{l}\text { Neste Oy } \\
\text { (Finland) } \\
\text { Neste Oil Inc. }\end{array}$ & $\begin{array}{l}\text { Oil and gas } \\
\text { exploration and } \\
\text { production }\end{array}$ & $\begin{array}{l}\text { Equity } \\
\text { acquisition }\end{array}$ & 30.0 & April \\
\hline NA & NA & $\begin{array}{l}\text { Schlumberger Ltd. } \\
\text { (France) } \\
\text { Pogo Producing Co. }\end{array}$ & $\begin{array}{l}\text { Oil and gas } \\
\text { exploration and } \\
\text { production }\end{array}$ & $\begin{array}{l}\text { Equity } \\
\text { acquisition }\end{array}$ & 26.0 & First quarter \\
\hline Panterra Petroleum & $\begin{array}{l}\text { Oil and gas } \\
\text { exploration and } \\
\text { production }\end{array}$ & $\begin{array}{l}\text { Louis Dreyfus et Cie } \\
\text { (France) } \\
\text { Louis Dreyfus Natural } \\
\text { Gas Corp. }\end{array}$ & $\begin{array}{l}\text { Oil and gas } \\
\text { exploration and } \\
\text { production }\end{array}$ & $\begin{array}{l}\text { Property } \\
\text { acquisition }\end{array}$ & 11.0 & April \\
\hline $\begin{array}{l}\text { Eastern American } \\
\text { Energy Corp. }\end{array}$ & Petroleum refining & $\begin{array}{l}\text { Andrew Sarios } \\
\text { (Canada) } \\
\text { Santa Fe Energy } \\
\text { Riesources Inc. }\end{array}$ & $\begin{array}{l}\text { Oil and gas } \\
\text { exploration and } \\
\text { production }\end{array}$ & $\begin{array}{l}\text { Property } \\
\text { acquisition }\end{array}$ & 7.4 & January \\
\hline Unidentified & NA & $\begin{array}{l}\text { Kingston Oil and Gas } \\
\text { plc } \\
\text { (United Kingdom) }\end{array}$ & $\begin{array}{l}\text { Oil and gas } \\
\text { exploration and } \\
\text { production }\end{array}$ & $\begin{array}{l}\text { Equity } \\
\text { acquisition }\end{array}$ & 3.0 & May \\
\hline $\begin{array}{l}\text { Signal Treating } \\
\text { Service Inc. }\end{array}$ & NA & $\begin{array}{l}\text { Lontho plc } \\
\text { (United Kingdom) } \\
\text { Hondo Oil and Gas } \\
\text { Co. }\end{array}$ & Petroleurn refining & $\begin{array}{l}\text { Asset } \\
\text { acquisition }\end{array}$ & 2.5 & October \\
\hline EOTT Energy Corp. & $\begin{array}{l}\text { Natural gas } \\
\text { transmission, storage }\end{array}$ & $\begin{array}{l}\text { Royal Dutch/Shell } \\
\text { Group } \\
\text { (U.S., Netherlands) } \\
\text { Shell Oil }\end{array}$ & $\begin{array}{l}\text { Crude pipeline, } \\
\text { storage }\end{array}$ & $\begin{array}{l}\text { Asset } \\
\text { acquisition }\end{array}$ & NA & November \\
\hline $\begin{array}{l}\text { Natlonal Auto/ } \\
\text { Truckstops Inc. }\end{array}$ & $\begin{array}{l}\text { Gasoline service } \\
\text { stations, c-stores }\end{array}$ & $\begin{array}{l}\text { British Petroleum } \\
\text { (United Kingdom) } \\
\text { BP America }\end{array}$ & $\begin{array}{l}\text { Petroleum } \\
\text { marketing }\end{array}$ & $\begin{array}{l}\text { Asset } \\
\text { acquisition }\end{array}$ & NA & December \\
\hline
\end{tabular}

NA $=$ Not available.

See notes at end of table. 
Table A1. Completed Transactions by Size in the Petroleum Industry from January 1993 Through December 1993-Acquisitions and Divestitures (Continued)

\begin{tabular}{|c|c|c|c|c|c|c|}
\hline $\begin{array}{l}\text { Acquiring } \\
\text { Company }\end{array}$ & $\begin{array}{c}\text { Acquiring } \\
\text { Company Activity }\end{array}$ & $\begin{array}{l}\text { Affected } \\
\text { Company }\end{array}$ & $\begin{array}{c}\text { Affected } \\
\text { Company Activity }\end{array}$ & $\begin{array}{c}\text { Type of } \\
\text { Transaction }\end{array}$ & $\begin{array}{c}\text { Size of } \\
\text { Transaction } \\
\text { (million dollars) }\end{array}$ & $\begin{array}{c}\text { Date of } \\
\text { Transaction }\end{array}$ \\
\hline & & \multicolumn{3}{|c|}{ Divestitures (Continued) } & & \\
\hline Shell Oll Co. & $\begin{array}{l}\text { Integrated petroleum } \\
\text { operations }\end{array}$ & $\begin{array}{l}\text { British Petroleum } \\
\text { (United } \\
\text { Kingdom) } \\
\text { BP America Inc. }\end{array}$ & $\begin{array}{l}\text { Petroleum } \\
\text { marketing }\end{array}$ & $\begin{array}{l}\text { Asset } \\
\text { acquisition }\end{array}$ & NA & June \\
\hline $\begin{array}{l}\text { Steuart } \\
\text { Investment Co. }\end{array}$ & Investment holdings & $\begin{array}{l}\text { Agip Petroli } \\
\text { (Italy) } \\
\text { Steuart } \\
\text { Petroleum Co. }\end{array}$ & $\begin{array}{l}\text { Oil supplier, } \\
\text { gasoline service } \\
\text { stations }\end{array}$ & $\begin{array}{l}\text { Equity } \\
\text { acquisition }\end{array}$ & NA & June \\
\hline
\end{tabular}

NA $=$ Not available.

Sources: See page 39. 
Table A2. Completed Transactions by Size in the Ccial Industry from January 1993 Through December 1993-Acquisitions and Divestitures

\begin{tabular}{|c|c|c|c|c|c|c|}
\hline $\begin{array}{l}\text { Acquiring } \\
\text { Company }\end{array}$ & $\begin{array}{c}\text { Acquiring } \\
\text { Company Activity }\end{array}$ & $\begin{array}{l}\text { Affected } \\
\text { Company }\end{array}$ & $\begin{array}{c}\text { Affected } \\
\text { Company Activity }\end{array}$ & $\begin{array}{c}\text { Type of } \\
\text { Transaction }\end{array}$ & $\begin{array}{c}\text { Size of } \\
\text { Transaction } \\
\text { (million dollars) }\end{array}$ & $\begin{array}{l}\text { Date of } \\
\text { Transaction }\end{array}$ \\
\hline & & \multicolumn{3}{|c|}{ Acquisitions } & & \\
\hline $\begin{array}{l}\text { Hanson plc } \\
\text { (United Kingdom) }\end{array}$ & Diversified holdings & $\begin{array}{l}\text { Santa Fe Pacific } \\
\text { Corp. }\end{array}$ & $\begin{array}{l}\text { Railroads, precious } \\
\text { metals, coal mining }\end{array}$ & $\begin{array}{l}\text { Asset } \\
\text { acquisition/ } \\
\text { swap }\end{array}$ & 425.0 & June \\
\hline $\begin{array}{l}\text { Rheinbraun AG } \\
\text { (Germany) } \\
\text { Consol Inc. }\end{array}$ & Coal mining & $\begin{array}{l}\text { Island Creek Coal } \\
\text { Co. }\end{array}$ & Equity acquisition & $\begin{array}{l}\text { Equity } \\
\text { acquisition }\end{array}$ & 221.0 & April \\
\hline \multirow{2}{*}{$\begin{array}{l}\text { Bruntcliffe } \\
\text { Investments plc } \\
\text { (United Kingdom) }\end{array}$} & Coal mining & Lorsen Holdings & Coal mining & $\begin{array}{l}\text { Equity } \\
\text { Acquisition }\end{array}$ & NA & April \\
\hline & & \multicolumn{3}{|c|}{ Divestitures } & & \\
\hline Hanson plc & Diversified holdings & $\begin{array}{l}\text { Olympia and York } \\
\text { Ltd. } \\
\text { (Canada) } \\
\text { Santa Fe Pacific } \\
\text { Corp. }\end{array}$ & $\begin{array}{l}\text { Railroads, precious } \\
\text { metal, coal mining }\end{array}$ & $\begin{array}{l}\text { Asset } \\
\text { acquisition }\end{array}$ & 425.0 & June \\
\hline
\end{tabular}

$N A=$ Not available.

Sources: See p. 39. 
Table A3. Completed Transactions by Size in Other Energy Industries from January 1993 Through December 1993-Acquisitions

\begin{tabular}{|c|c|c|c|c|c|c|}
\hline $\begin{array}{l}\text { Acquiring } \\
\text { Company }\end{array}$ & $\begin{array}{c}\text { Acquiring } \\
\text { Company Activity }\end{array}$ & $\begin{array}{l}\text { Affected } \\
\text { Company }\end{array}$ & $\begin{array}{c}\text { Affected } \\
\text { Company Activity }\end{array}$ & $\begin{array}{c}\text { Type of } \\
\text { Transaction }\end{array}$ & $\begin{array}{l}\text { Size of } \\
\text { Transaction } \\
\text { (million dollars) }\end{array}$ & $\begin{array}{l}\text { Date of } \\
\text { Transaction }\end{array}$ \\
\hline & & \multicolumn{3}{|c|}{ Acquisitions } & & \\
\hline
\end{tabular}

Sources: See p. 39. 


\section{Sources}

Informational material used in compiling Tables A1, $\mathrm{A} 2$, and $\mathrm{A} 3$ :

- The Wall Street Journal, various issues, 1993 and 1994.

- Business Week, various issues.

- Company financial reports: annual reports to stockholders, annual reports on Securities and Exchange Commission (SEC) Form 10-K, and filings on SEC Schedule 13-D.

- Moody's International Manual, 1993 and 1994. Moody's Investors Service, New York, NY.

- Oil and Gas Journal, various issues, 1993 and 1994. Pennwell Publishing Company, Tulsa, OK.

- SEC News Digest, selected issues, 1993. U.S. Securities and Exchange Commission, Washington, DC.
- Southwest Newswire.

- The Merger Yearbook U.S.International Edition 1994. Securities Data Company, New York, NY.

- Oil and Gas Investor, September 1993 and April 1994. Hart Publications, Inc., Denver, CO.

- U.S. Oil Week, various issues, 1993 and 1994. Capital Publishing Group, Alexandria, VA.

- Coal, various issues, 1993 and 1994. Maclean Hunter Publishing Co., Chicago, IL.

- Coal Outlook, various issues, 1993. Pasha Publications, Arlington, VA.

- Company press releases. 